\title{
Europeanization of the Estonian Electricity Sector: Historical Legacies and Security Concerns
}

\author{
Madis Ehastu \\ West Virginia University
}

Follow this and additional works at: https://researchrepository.wvu.edu/etd

\section{Recommended Citation}

Ehastu, Madis, "Europeanization of the Estonian Electricity Sector: Historical Legacies and Security Concerns" (2011). Graduate Theses, Dissertations, and Problem Reports. 729.

https://researchrepository.wvu.edu/etd/729

This Thesis is protected by copyright and/or related rights. It has been brought to you by the The Research Repository @ WVU with permission from the rights-holder(s). You are free to use this Thesis in any way that is permitted by the copyright and related rights legislation that applies to your use. For other uses you must obtain permission from the rights-holder(s) directly, unless additional rights are indicated by a Creative Commons license in the record and/ or on the work itself. This Thesis has been accepted for inclusion in WVU Graduate Theses, Dissertations, and Problem Reports collection by an authorized administrator of The Research Repository @ WVU. For more information, please contact researchrepository@mail.wvu.edu. 
Europeanization of the Estonian Electricity Sector: Historical Legacies and Security Concerns

\author{
Madis Ehastu
}

Thesis submitted to the Eberly College of Arts and Sciences at West Virginia University in partial fulfillment of the requirements for the degree of

Master of Arts in History

\author{
Robert Blobaum, Ph.D., Chair \\ Katherine Aaslestad, Ph.D. \\ Elizabeth Fones- Wolf, Ph.D.
}

Department of History

Morgantown, West Virginia

2011

Keywords: Europeanization; Estonia; European Union; energy policy; electricity; historical legacy; energy security 


\section{ABSTRACT \\ Europeanization of the Estonian Electricity Sector: Historical Legacies and \\ Security Concerns}

\section{Madis Ehastu}

Estonia, generally considered a Europhile country, is showing the first signs of opposition to supranational European Union (EU) policies. This is because the EU's energy- and climate policy's trinity of policy directions- creation of an internal market, security of supply and environmental sustainability- are problematic in regard to the the case of Estonian electricity sector. The Estonian actors' response to adaptational pressures caused by the EU, a process that is generally understood as Europeanization, thus provides us with a useful case study to determine what conditions limit the EU's attempts to influence domestic politics. Research indicates that the main reason for Estonian opposition is the country's historical legacy in the form of the oil shale complex that was built during the Soviet rule. The small size of the Estonian electricity market, the relative poverty of the state and the inability of the politicians to decide for the future development of the sector have been identified as factors that along with the historical legacy continue to influence Estonian domestic energy- and climate policy. Because of this complex interdependence of factors, the EU's aims to create an open internal market and to increase environmental sustainability cannot be achieved without threatening the security of Estonia's domestic electricity supply. This, in turn, is because the EU- wide policy has been driven by states, such as Germany, France and United Kingdom that have not taken into account the peculiar conditions in the EU's Eastern borderlands. This, in turn, has led Estonia to use the energy security "clause" to gain support on the EU- level and to defend its interests. 
I have written the work independently. All works of other scholars, their principled positions, and data from written sources and from elsewhere that have been used in preparing this this work have been cited.

Ithe author's signaturel 


\section{Table of Contents}

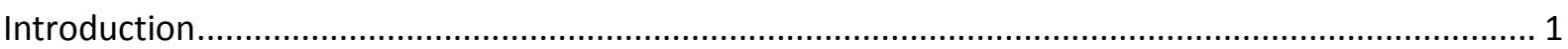

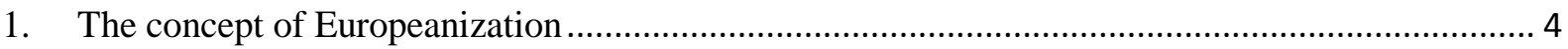

2. Importance of the electricity sector: energy security................................................................. 14

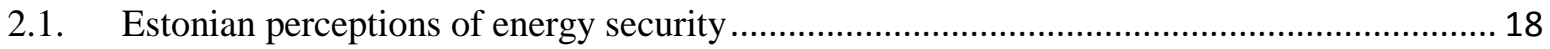

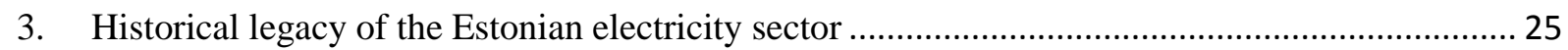

4. Empirical findings and analysis: development of EU and Estonian energy policies ................... 28

4.1. 1991- 1995: Early stages of EU and Estonian energy policies.......................................... 28

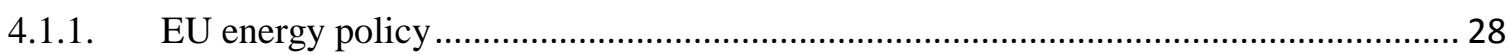

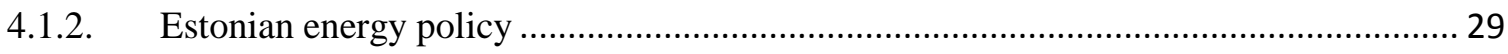

4.2. 1995- 2004: Estonia as an EU candidate state.................................................................... 32

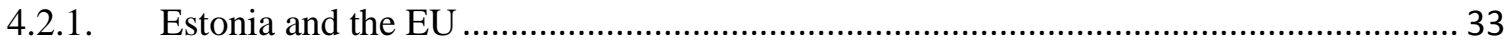

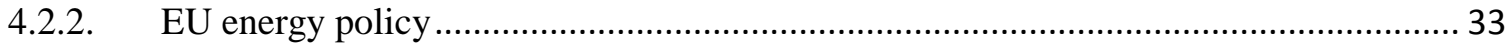

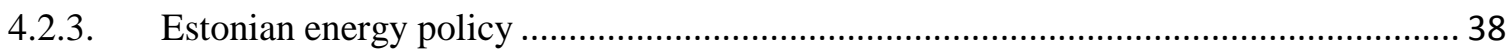

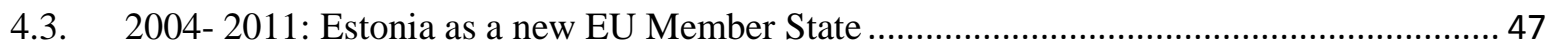

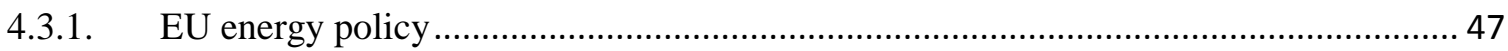

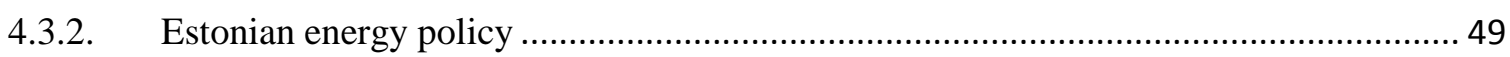

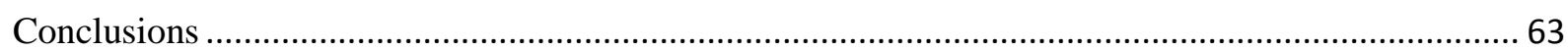

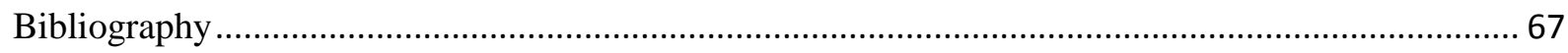




\section{Introduction}

Estonia, generally considered a Europhile country, is showing the first signs of opposition to supranational European Union (EU) policies. In the field of electricity market reform, it has lobbied for stricter third party access to the European internal market and has gone to court together with Poland against the European Commission's nationally allocated greenhouse gas emission quotas. According to a study by the Estonian electricity transmission system operator Elering OÜ, Estonian electricity production will in 2016 decrease to the level where domestic supply will be unable to cover approximately $20-25 \%$ of peak consumption. ${ }^{1}$ By 2025 , if no additional production capacities are installed, the number will probably increase to almost $80 \%$. This means that electricity will have to be imported from other states. Because electricity is seen as a strategic commodity to the functioning and development of a state and its economy, the decreasing supply appears as a security threat. All states seek to create conditions that will guarantee the availability of domestic electricity to avoid dependence on foreign energy supplies. Estonia, at the moment has, failed to do so for the near future.

Estonia's domestic electricity supply decrease is not based on dysfunctional energy generation capacity, but rather on a change of convergence related to its membership in EU. Upon negotiating accession to the EU, Estonia agreed to harmonize its legislation and standards wit that of the EU. The problem is that almost all of Estonian electricity is produced in an environmentally unfriendly way and Estonia is required to cut emissions either by improving the technology or finding new ways to produce electricity.

European integration has led various stakeholders in the Estonian electricity sector to respond to adaptational pressures because of a 'misfit' between EU- and domestic level policies. This process is generally understood as Europeanization. Unlike its approach in many other fields, Estonia has been actively opposing EU requirements to implement change in its electricity sector. It is thus essentially opposing Europeanization. Hence, Europeanization of the Estonian electricity sector provides us with a useful case study to learn about the concept of Europeanization, the main purpose of this thesis.

\footnotetext{
${ }^{1}$ OÜ Elering, "Eesti Elektrisüsteem varustuskindluse aruanne (Security of supply report of the Estonian electricity sector)," Tallinn (2010): 14.
} 
In this context, the main research question of the thesis is to explore the conditions that limit the effectiveness of the EU's attempts to influence domestic politics. Or particularly, what are the conditions that have led Estonia to oppose Europeanization in its electricity sector?

The more specific research tasks are the following: (1) to review the relevant Europeanization literature and to derive hypotheses from it, (2) to study the Europeanization process in a historical perspective and to find the historical legacies that influence contemporary decision- making, and (3) to find the conditions that limit Europeanization in the case of the Estonian electricity sector.

The theoretical framework of this study is drawn from relevant Europeanization literature. Previous works suggest that the deepest understanding of the process of Europeanization in a specific case can be achieved by studying it in historical perspective, paying particular attention to historical legacies that have a longstanding influence. Thus, change in the Estonian electricity sector should be studied since its establishment in the early $20^{\text {th }}$ Century. Of specific interest are the larger infrastructural objects that were built during the period of Soviet rule as it is suggested that such legacies have a strong influence on the process of Europeanization. Attention is also paid to the unique characteristics of the electricity sector and its importance for a state's economy and security. It is thus expected that profound changes in the electricity sector will be met with greater opposition than in other sectors.

Since Estonia has joined the EU relatively recently, greater attention is paid to scholarship on Europeanization of candidate and new member states. Europeanization is generally considered to be a two- way process- Member States upload policies to and download policies from the EU level. For candidate states, however the process is instead characterized by conditionality, meaning that it is a one- way process where EU policies are only downloaded. Hence, Europeanization can take different forms depending on the relationship between a state and the EU. Thus, the empirical part of the thesis is divided into three parts, focusing on different aspects of the EU's influence on Estonia.

In the first period (1991- 1995, the first four years of Estonian reindependence), Estonian politics were influenced relatively little by the EU. Thus, the period can give some insights about the values and beliefs of the politicians about the further development of the electricity sector was 
seen. The second period (1995- 2004, Estonia as a candidate state) is characterized by the strongest influence of the EU on Estonian politics because of its stronger negotiating position. This allows us to identify the mechanism of Europeanization and to evaluate the conditions under which Europeanization was effective in the case of a candidate state. After Estonia became an EU Member State, it also received the right to upload policies to the EU level. This period allows us to evaluate the conditions under which EU's influence is effective on the domestic level in the case of a new Member State.

The research relies on various primary and secondary sources such as pieces of legislation, policy papers, various reports, journal and newspaper articles, and academic books. The sources give a good idea of the official policies of both the EU and Estonia. The policies' background is somewhat revealed in various academic works and newspaper articles, but not entirely. For this reason, more comprehensive and profound results can be achieved in the future by conducting interviews with some of the people involved in the process. 


\section{The concept of Europeanization}

European integration has generated a number of research agendas. The impact of the EU on the candidate or member states' polities, policies and politics has been researched through conceptual models such as multi- level governance, policy networks, and Europeanization. Of these, Europeanization is perhaps best suited for policy outcomes research on the domestic level. Europeanization has been criticized as an amalgam of 'meso' and 'grand' theories of European integration as it is drawing from neo- functionalism, liberal intergovernmentalism, neoinstitutionalism and from social constructivist approaches. ${ }^{2}$ Thus, Europeanization is in itself an approach, as it provides a simplified model of reality that has explanatory power. As Angelos Sepos writes "borrowing insights with rationalist and constructivist roots can often be useful in explaining [different] case studies."

Not a new term, Europeanization emerged as a theme in the 1980s and was deployed as a research agenda relatively recently. ${ }^{4}$ Its popularity, especially related to the Central Eastern European Countries (CEEC), has been gradually increasing. ${ }^{5}$ There are ongoing discussions over the definition of the concept, but all reveal a number of common themes and conclusions. One of the first attempts to capture its meaning was made by Robert Ladrech in 1994: Europeanization, he writes can be understood as "an incremental process reorienting the direction and shape of politics to the degree that EC political and economic dynamics become part of the organizational logic of national politics and policy- making." ${ }^{.6}$ The definitions slightly differ according to the scholars' approaches and thus emphasis is placed on its different aspects. According to Sepos, Radaelli argues from a similar perspective saying that

"Europeanization consists of processes of construction, diffusion and institutionalization of formal and informal rules, procedures, policy paradigms, styles, 'ways of doing things' and shared beliefs and norms that are first defined and consolidated in the EU policy

\footnotetext{
${ }^{2}$ Angelos Sepos, The Europeanization of Cyprus: Polity, Policies and Politics (New York: Palgrave, 2008): p 1.

${ }^{3}$ Ibid.

${ }^{4}$ Ibid.

${ }^{5}$ According to Kevin Featherstone and Claudia Maria Radaelli, The politics of Europeanization (Oxford University Press, 2003): 5; and Ulrich Sedelmeier, „Europeanization in new member states and candidate states,“ LivingReviews in European Governance, 6(2011):7.

${ }^{6}$ Cited in Ian Bache, Europeanization and multilevel governance: cohesion policy in the European Union and Britain (Rowman and Littlefield, 2008): 10.
} 
process and then incorporated in the logic of domestic discourse (national and subnational), political structures and public policies."7

A slightly different point of view is given by scholars working with the notion of référentiel, arguing that "there is Europeanization when the EU becomes the referential (Sepos' emphasis) (i.e. the reference point) of domestic political action." ${ }^{\prime 8}$ Olsen perhaps gives the broadest definition as he distinguishes between five different uses of the term: it had been understood as changes occurring in external territorial boundaries, development of institutions of governance at the European level, penetration of national and sub- national systems of governance, exporting forms of political organization and governance that are typical and distinct for Europe beyond the European territory and as a political project aiming at a unified and politically stronger Europe. ${ }^{9}$ Schimmelfenning and Sedelmeier provide the simplest definition by saying that Europeanization is "a process in which states adopt EU rules." 10 Sedelmeier puts it more simply, saying that the term is being generally used as shorthand for 'influence of the EU' or 'domestic impact of the EU'. ${ }^{11} \mathrm{He}$ also identifies the main research questions being asked when studying Europeanization and says that they can be generally boiled down to the following one: "under what conditions are the EU's attempts to influence candidate countries effective? Or in other words: what factors explain variation in the EU's influence across countries and issue areas?"12

It is important to acknowledge that Europeanization is not synonymous with convergence, harmonization or European integration, as it is concerned with what happens once EU institutions are in place and produce their effects. ${ }^{13}$ Thus, "it is not concerned with why and how Member States produce European integration, and whether the EU is more inter- governmental or supranational- rather it aims to bring domestic politics back into understanding European integration." 14 Consequently, whereas European integration theories aim to explain the dynamics

\footnotetext{
${ }^{7}$ Sepos 2008, p 2.

${ }^{8}$ Ibid, p2.

${ }^{9}$ Johan P.Olsen, „The Many Faces of Europeanization,“ Journal of Common Market Studies, 40(2002): 3-4.

${ }^{10}$ Frank Schimmelfenning and Ulrich Sedelmeier, The Europeanization of Central and Eastern Europe, (Cornell University Press, 2005): 7.

${ }^{11}$ Sedelmeier 2011, p 5.

12 Ibid., p 9.

${ }^{13}$ Sepos 2008, p 2.

${ }^{14}$ Ibid., p 3.
} 
and outcomes of European integration, Europeanization is a better way of understanding domestic effects. $^{15}$

Specifically, Börzel and Risse have identified two preconditions for Europeanization to occur. First, Europeanization must be 'inconvenient', essentially meaning that there must be some degree of 'misfit' between EU- level processes compared to domestic processes. "This degree of misfit leads to adaptational pressures, which constitute a necessary but not sufficient condition for explaining domestic change." ${ }^{16}$ Second, various facilitating actors at the domestic level must respond to adaptational pressures. ${ }^{17}$

Scholars have also identified a number of Europeanization mechanisms, generally depending on the theoretical basis of the research or the type of process they induce (top- down or bottomup). ${ }^{18}$ Sepos identifies two main approaches: the rationalist approach whose emphasizes the notion of 'optimality' and the constructivist approach which logic is based on the notion of 'appropriateness'. In the former, actors follow a certain policy because they believe it would reap the greatest rewards whereas in the latter, actors follow a certain policy because they perceive it to be appropriate in terms of their beliefs, ideas and norms. Sedelmeier agrees with this view, but points out that both schools generally draw on the institutionalism theory for their research, with some exceptions. Cristoph Knill and Dirk Lehmkull are more specific as they have identified three mechanisms of domestic impact of European policy-making: European policies might be very prescriptive, and demanding Member States to comply with specific requirements; they may be limited to changing domestic opportunity structures; or they may be without any direct institutional impact at all since they primarily aim to change domestic beliefs and expectations. ${ }^{19}$ The first mechanism resembles most the logic of 'optimality whereas the third one resembles most the logic of 'appropriateness'. They also point out that the successfulness of the Europeanization process consists of two steps: the existing constellation and opportunity structures at the domestic level which determine the direction of domestic change. Thus, the

\footnotetext{
${ }^{15}$ Ibid., p 3.

${ }^{16}$ Tanja A.Börzel and Thomas Risse, „Conceptualizing the Domestic Impact of Europe,“ in The Politics of Europeanization, ed. Keith Featherstone and Claudio Radaelli (Oxford University Press, 2003): 2.

${ }^{17}$ Sepos 2008, p 3.

18 Ibid., p 3.

${ }^{19}$ Cristoph Knill and Dirk Lehmkull, „The national impact on European Union regulatory policy: Three Europeanization mechanisms, “" European Journal of Political Research 41(2002):257.
} 
authors rely on an institutionalist approach. ${ }^{20}$ These insights help to understand what to look for when evaluating the process of Europeanization. Accordingly, there must be a 'misfit' between EU and domestic policy levels and facilitating actors who respond to adaptation pressures. The process itself varies between the logics of optimality and appropriateness.

In relation to Central- and Eastern European Countries (CEECs), research has focused on "contemporary structures, institutions and actor dispositions such as power asymmetries between the EU and the candidates, the size and credibility of EU incentives for reform, the state of democratization, the composition of East European governments and the constellation of veto players in their political systems." ${ }^{21}$ Recently, more attention has been paid to the historical legacies of these countries from both the communist period and before, and how they affect the Europeanization process. This is increasingly important in the case of new Member States where Europeanization is increasingly dependent on "political structures and resource endowments that have been shaped by legacies." Since further enlargement has lost momentum, Europeanization's successfulness and its limits might be "conditioned by historical legacies both in East European countries and East- West relations." 22 Historical legacy is sometimes used as synonymous with path- dependency, but it is argued that the "scope for political actors to appropriate, reject or construct historical legacies may be greater than commonly assumed" because they do have the ability, as rational actors, to consciously respond to their environment by reconfiguring their legacies "even if the successful capacity of actors to reconstruct and reinvent their past histories or geographical space will be determined by the prevailing 'structural constraints and historical circumstances'."23 This suggests that Estonian energy policy is not entirely determined by historical legacies, although it may be greatly influenced by it.

Cirtautas and Schimmelfennig introduce the role of legacies in three different ways. ${ }^{24}$ First, legacies as deep conditions give the explanations of enlargement and Europeanization more historical and causal depth, attaining the "status of proximate causes or intermediate steps in the causal path from legacies to contemporary outcomes" and explaining the "contemporary

\footnotetext{
${ }^{20}$ Knill \& Lehmkull 2002, p 262.

${ }^{21}$ Arista Maria Cirtautas and Schimmelfennig, Frank, „Europeanization Before and After Accession: Conditionality, legacies and Compliance,“ European-Asia Studies 62(2010): 422 .

${ }^{22}$ Ibid, p 422.

${ }^{23}$ Ibid., p 430

${ }^{24}$ Ibid., p 431- 437
} 
constellation of actors, interests, ideas, power and institutions" as being shaped by the communist and pre- communist periods. ${ }^{25}$ Second, legacies as enduring conditions suggest that the relevance of the legacies varies over time as they might be "sidelined or overridden by other powerful short- term factors" but felt increasingly in the longer run. ${ }^{26}$ Third, legacies as encompassing conditions refer to a 'deeper' factor that is causing both the explanatory factor ${ }^{27}$ and the outcome, meaning that both a state's receptivity to change and its effects are caused by historical legacies. ${ }^{28}$

However, the most widely used approach to understand change in candidate countries and new Member States is the contrasted use of the term conditionality. Examples of this include: contrasting 'incentives' and 'normative pressure', 'conditionality' and 'convergence' through the 'spread of norms', 'external incentives' and 'social learning' or distinguishing between 'compliance' and 'communication'. ${ }^{29}$ They all derive from the notion of 'transformative power' of the EU, which rests largely on 'active' and 'passive leverage'. ${ }^{30}$ The latter refers to the attractiveness of EU membership and the expected benefits that follow; the former refers to the criteria of membership that consist of both the acquis communautaire and transfer of European beliefs, values and norms to the domestic level. Theory thus suggests that, in case of Europeanization, change has occurred due to EU's 'transformative power', but its nature depends on the specific case studied.

The most appropriate model for understanding change in both Central and Eastern Europe candidate and new Member States that includes the approaches described above, was introduced by Schimmelfennig and Sedelmeier in their book The Europeanization of Central and Eastern Europe (2005). Sedelmeier has since improved it in a recent literature review article. The model differentiates between theoretical origins (rationalist institutionalism vs. constructivist institutionalism) and the driving force behind the change (whether driven domestically or by the

\footnotetext{
${ }^{25}$ Ibid., p $431-432$

${ }^{26}$ Ibid., p 432

27 That, in this case, is explained as being an excessively shallow explanation of the Post- Communist regime diversity.

${ }^{28}$ Cirtautas \& Schimmelfennig 2010, p 435.

${ }^{29}$ Sedelmeier 2011, p 11.

${ }^{30}$ Tim Haughton, "When Does the EU Make a Difference? Conditionality and the Accession Process in Central and Eastern Europe,” Political Studies Review 5(2007): 235.
} 
EU). Against this background, they created a taxonomy that helps to visualize this interdependence (Figure 1).

\section{Logic of rule adaptation}

\begin{tabular}{l|l|l} 
Principal actor in rule & $\begin{array}{l}\text { Logic of consequences (rational } \\
\text { adoption process }\end{array}$ & $\begin{array}{l}\text { Logic of appropriateness } \\
\text { (constructivist institutionalism) }\end{array}$ \\
\hline EU- driven & External incentives model & Social learning model \\
\hline CEEC- driven & Lesson- drawing model & Lesson- drawing model \\
\hline
\end{tabular}

\section{Figure 1: Alternative mechanisms of Europeanization}

Rational institutionalism follows the logic of consequences (or logic of 'optimality') that mainly focuses on the EU-s use of its active leverage and the processes it induces on the domestic level. The EU's strategy is to require clear and credible demands of conditionality while offering adequate rewards and linkages to Western Europe while sustaining efficient monitoring capacity. ${ }^{31}$ The success of Europeanization depends on factors that determine the adaptation costs for the governments because of historical legacies, on actor density and the number of veto players, and on the administrative capacities of the target country. ${ }^{32}$ Constructivist institutionalism, on the other hand, follows on the logic of appropriateness that focuses on the mechanisms of socialization and persuasion and on how convinced are the candidate and new member states of the legitimacy and the intrinsic value of the EU demands, rather than material incentives. In this approach, the EU's strategy is merely to promote a set of rules that is seen as legitimate by the target states and doing so through a process that is also seen as being appropriate. If the candidate and new member states consider the EU's conditions as legitimate, they are more likely to adopt the rules. Conditionality is thus seen as a process that involves the target state's participation whereby they success of change is more likely if soft tactics are used with low density demands. Europeanization is thus seen more as a learning process. Research indicates that it is more likely to occur when the rules are already codified internationally or in the EU's own acquis, when the rules are not more onerous than for the incumbents and when they are normatively consistent and based on a strong international consensus on the technical and political appropriateness of policy prescriptions. ${ }^{33}$ The target states' politics are characterized

\footnotetext{
${ }^{31}$ Sedelmeier 2011, p $13-14$.

${ }^{32}$ Ibid., p 14- 15.

${ }^{33}$ Ibid., p 15- 16.
} 
by the term normative resonance. Successful Europeanization is more likely when states identify themselves positively with the EU and when "there is a 'cultural match' or 'resonance' between EU demands and domestic rules and political discourses." An important factor is transnational networks that connect target countries' and EU elites who cooperate in adopting legislation. In this case, obstacles to EU influence are seen as institutional fluidity of programmes and the politicization of projects. The success is also dependent on the individuals involved. ${ }^{34}$

In Sedelmeier's review of CEECs Europeanization literature, this taxonomy has, to a large extent, proven to be effective. He, however, does point out a conceptual gap that is becoming more evident: the specification of domestic politics- veto players, actor density, domestic costs- as a mediating factor of EU's influence; these "often remain rather broad and are therefore subject to ad hoc operationalization. ${ }^{" 35}$ As a result, analysis of domestic costs is on kept separate from the impact of these costs, or in other words, a "target government's opposition is often taken as an indicator of high domestic adjustment costs, without sufficient analysis of why the these governments perceived EU demands are costly, and how such costs could have been operationalized and assessed prior to the analysis." ${ }^{36}$ This is also why analyzing facilitating actors in the process of Europeanization in the Estonian electricity sector is important, along with the historical legacies and domestic costs.

Electricity market liberalization specific literature has mostly concentrated on Western Europe. Paolo Nardi draws attention to four particular approaches in the literature: the creation of effective institutions at the EU level that is also be called 'Europeification' or 'Vergemeinschaftung (communitarization)', infrastructural integration and, in particular, the interconnection among Member States; emergence of a clear group of energy utilities characterized by a European dimension; and convergence towards similar standards in industrial organization, including market regulation, market opening and completion, and network unbundling. ${ }^{37}$ In his analysis of the electricity markets and policies, he relies on Börzel's taxonomy of Member State behavior and strategy in the Europeanization process that identifies

\footnotetext{
${ }^{34}$ Ibid., p 16.

${ }^{35}$ Ibid., p 30.

${ }^{36}$ Ibid., p 30.

${ }^{37}$ Paolo Nardi, "How Europeanized are the European Electricity Industries? A Cross- Country Analysis of Markets and Policies," unpublished (2009): 2-3.
} 
three groups of countries: pace- setters, foot- draggers and fence- sitters. ${ }^{38}$ Per Ove Eikeland looks at the third liberalization package through a multi- level governance approach as he describes the power asymmetries between the Commission and the Member States finding that the Commission was relatively successful in imposing its will and the opposing Member States, opinions were not decisive. He also finds that non- state actors and forces outside the EU had a relatively strong influence on the proposal for the third liberalization package, albeit indirectly. ${ }^{39}$ Fabio Domanico's analysis focuses on market incumbents in the electricity sector and on the problems that the liberalization process creates. He finds an increasing trend towards market concentration mostly due to the lack of interconnection between the Member States, lack of effective privatization in some Member States, ineffective unbundling, the absence of independent regulatory authorities and rules that foster the creation of 'national champions' ${ }^{40}$ David Levi- Faur analyzed the 'net impact' of Europeanization to the telecommunications and electricity sectors in 2002 and arrived at the conclusion that Europeanization was merely a mediating factor and that liberalization would have occurred even without the Commission's demands. ${ }^{41}$ In analyzing the Europeanization of the French electricity market, Pierre Bauby and Frédéric Varone observe four paradoxes: the electricity sector remains concentrated, creating a scope for incumbent operators to influence prices; an illiquid market due to the facts that companies are active both in production and in the retail market, and insufficient unbundling of network and supply activities; limited interconnections between Member States prevent the development of integrated EU energy markets; and lack of transparency benefits incumbents and undermines the position of new entrants. ${ }^{42}$ Finally, Laura Deitz, Lindsay Stirton and Kathryn Wright focus on nine South East European countries (SEE)- Albania, Bosnia- Herzegovina, Bulgaria, Croatia, Montenegro, the Former Yugoslav Republic of Macedonia, Romania, Serbia and the United Nations Mission on behalf of Kosovo- to evaluate whether the states in question

\footnotetext{
${ }^{38}$ Ibid., p 3-4.

${ }^{39}$ Per Ove Eikeland, "EU Internal Energy Market Policy: New Dynamics in Brussels Policy Game?” Fridtjof Nansen Institute Report 14(2008).

${ }^{40}$ Fabio Domanico, "Liberalization of the European Electricity Industry: Internal Market or National Champions?" Worldenergy.org (2007).

${ }^{41}$ David Levi- Faur, “On the 'Net Impact' of Europeanization. The EU's telecoms and electricity regimes between the global and the national," European Integration online Papers 6(2002).

${ }^{42}$ Pierre Bauby and Frédéric Varone, "Europeanization of the French electricity policy: four paradoxes," Journal of European Public Policy 14(2007).
} 
are able to meet the requirements of EU's energy related acquis communautaire. ${ }^{43}$ Because the performance levels of the SEE countries' governing institutions are much lower than of the EU 25 , they might not be able to successfully close the energy chapter of the acquis. They find that the most important attractions for Europeanization are EU's offers of private investment, technical policy- making competence and geopolitical security of supply whereas obstacles for Europeanization are unpopular domestic policy outcomes such as price increases that in turn creates challenges for the economy to develop at an adequate speed and undermines welfare. These are also the main reasons given as limits to Europeanization.

Of the articles briefly reviewed here, only the last addresses the conditions that affect the successfulness or limits of Europeanization. Particularly, the 'misfit' or even an obstacle to successful Europeanization is the relative poverty of the South East European states. The other articles mainly study the discrepancies between the Commission's policy goals and the reality in respective Western European electricity sectors. No generalizations on conditions that are suggested to be true in all cases of Europeanization are drawn. This is perhaps because it is recognized that conditions in each state are different, and because the studies mainly concentrated on only a small number of cases. I can thus expect that the Estonian case will have some unique characteristics that will help us to further understand Europeanization, and that its relative low level of development affected Europeanization at least in the earlier stages, as the case of SEE countries suggest.

In conclusion, a theoretical overview of the concept of Europeanization allows me to set the following hypotheses. In order for there to be Europeanization in the Estonian electricity sector, there must be a misfit that leads to adaptational pressures that can be described as inconvenient, and various facilitating actors must be identifiable. It is suggested that the deepest understanding of the case can be achieved by studying the sector in a historical perspective, while paying particular attention to its historical legacies.

Hypothesis 1: There is a misfit between EU level and domestic level policies that leads to adaptational pressures for the domestic facilitating actors.

Hypothesis 2: Historical legacies influence contemporary politics.

\footnotetext{
${ }^{43}$ Laura Deitz, Lindsay Stirton and Kathryn Wright, ,South East Europe’s electriicty sector: Attractions, obstacles and challenges of Europeanization,“ Utilities Policy 17(2009): 4-12.
} 
After establishing the misfit, the facilitating actors and the historical legacies, I will evaluate the mechanism(s) through which Europeanization has occurred. In order to do so, I will evaluate which logic, optimality or appropriateness, best describes the process. This essentially helps us to understand the factors influencing the process and whether it characterized more by the external incentives, the social learning or lesson- drawing model.

Hypothesis 3: Europeanization has occurred because of EU-s superior bargaining position that has led to an ability to threaten with noncooperation and thereby force Estonia to make concessions (external incentives model).

Hypothesis 4: Europeanization has occurred because Estonia has been motivated by internalized identities, values and norms, and thus legitimacy of rules, appropriateness of behavior, persuasion and complex learning characterize the process of rule transfer and rule adoption in the Estonian electricity sector (social learning model).

Hypothesis 5: Europeanization has been induced by Estonia itself because the EU requirements have been seen as effective remedies to inherently domestic needs and policy challenges (lessondrawing model).

(Hypotheses 6 and 7 can be found in the end of the next chapter.)

In the final part, I aim to evaluate whether Europeanization in the Estonian electricity sector has been successful or not, i.e. is there still a misfit or have the EU and domestic level policies fully harmonized. After establishing this, I aim to point out the factors that explain variation in the EU's influence in the case of the Estonian electricity sector.

In order to achieve the goals described above, I will rely on primary sources such as laws, regulations, policy papers and discussions in Riigikogu (Estonian Parliament). It would have also been useful to conduct in- depth interviews with specialists to get more precise answers to my questions, but this must be left to future research. I also use secondary sources, such as books, journal articles and newspaper articles. 


\section{Importance of the electricity sector: energy security}

The ultimate goal of a rational individual, community or state is to survive. Consequently, any actor aims to increase its security by having as few existential threats as possible. Or in other words, limiting issues that are "presented as posing an existential threat to a designated referent object (traditionally, but necessarily, the state, incorporating environment, territory and society)." 44 The word "to present" indicates that security is a tool that can be politically used against or through a "referent object." Existential threats thus have to be perceived as being threats before counter- actions can be taken. This is understood as the normative dilemma in the concept security. The term is thus a word that can be used as a political tool in creating "the other" through fear and used for oppressive action or social and political exclusion. Or as Huysmans explains, security is a thick signifier, a concept with different meanings that organizes social relations into security relations. ${ }^{45}$ Security or threats, for that matter, are always social constructs that are perceived by a social group.

An understanding of energy security essentially comes from threats perceived by a social group to their ability to consume energy in order to maintain and develop as a society. This is a social relation as other societies use energy for the same aims.

Security in terms of energy is relevant because of the unequal distribution of natural resources in the world. It is a longstanding problem, whether talking about gold or silver mines in the $17^{\text {th }}$ century or deposits of oil, gas and uranium today. "John Locke's insistence of the primacy of contract over conflict in the debate with his mercantilist contemporaries was as valid as it is now.",46

Looking at history, energy has played a substantial role in conflict. One could argue that energy resources played a major role in both Gulf Wars and the escalation of conflict in Libya today has partially happened because of its energy resources. The peaceful utilization of energy resources was also one of the underlying reasons in founding the European Union (EU). The establishment of two of the three Communities (EURATOM and European Coal and Steel Community) of the

\footnotetext{
${ }^{44}$ Barry Buzan, Ole Wæver and Jaap de Wilde, Security: a new framework for analysis (Lynne Rienner Publishers, 1998), 21.

${ }^{45}$ Jef Huysmans, „Security! What Do You Mean? From Concept to Thick Signifier,“ European Journal of International Relations 4(1998).

${ }^{46}$ Keppler 2007, p 5.
} 
European Communities was carried by this idea. At that time, coal and steel were two of the most important substances for industry after the Second World War. A supranational authority was thus created in order to strengthen and control the markets and ensure peace. ${ }^{47}$

In comparison, Europe has been unfortunate in terms of allocation of energy resources by nature. It is facing a gradually growing dependency on imports as domestic resources are being exhausted by ever- rising demand. If "business as usual" is maintained, the European Union's energy import dependence will grow from 54\% of total EU consumption today to about $70 \%$ in 2030. Reliance on imports of natural gas is expected to increase from $57 \%$ to $84 \%$ by 2030 , of oil from $82 \%$ to $93 \%{ }^{48}$ There are only a limited number of energy suppliers, frequently in geopolitically unstable regions (e.g. Middle East, North Africa and Central Asia). The rapid growth of China and India is increasing competition over the suppliers' energy resources. Some observers have also been "startled by China's dynamism in securing physical energy supplies, in particular in African countries." ${ }^{49}$ The pressure on global energy is thus intense, carrying both political and economic risks. Global demand for oil is expected to grow by $41 \%$ by 2030 but it is unclear how supply will keep up. The International Energy Agency (IEA) sees only modest increases in oil production because of constraints on investment in its 2010 World Energy Outlook. ${ }^{50}$ It not only increases risk of supply failure but also growth in prices.

The best way to overcome these problems in the EU is unclear. Some energy experts support the view that the Community should have the task of formulation energy security policy. They see a solution to the supply and price problems through a liberalized market where energy exchange between Member States is guaranteed at any time (e.g. by stock exchange and solidarity options at a time of crisis). A transnational authority should oversee the system because "a failure to adopt adequate measures in one Member State can have serious consequences for the operation of the internal market throughout the EU and beyond." ${ }^{51}$ Thus a degree of cooperation should be created and a Community framework of action adopted as it is difficult to adopt broader necessary measures, such as creating a stable relationship between importing and exporting

\footnotetext{
${ }^{47}$ Tahsin Hakan Ertuna, „Competition Law in the Electricity Market: Liberalization and its Consequences,“ Ankara Bar Review 2(2010): 35.

${ }^{48}$ EEA Report No 8/2006: Energy and Environment in the European Union.

${ }^{49}$ Keppler 2007, p 6.

${ }^{50}$ IEA World Energy Outlook 2010, p 6.

${ }^{51}$ Haghighi 2008, p 463.
} 
countries that are undertaken at the Member State level alone. Other energy experts argue that "national governments can better guarantee the security of energy supply independently from the community, due to their familiarity with their own specific market." 52

These two divergent views are forming the approaches in the discussion on the division of competencies in the European Community. It is thus a twofold problem as it has an internal and an external dimension. The challenge is not just to find solutions for energy supply but also providing energy at a with reasonable price and keeping sustainable development in mind. ${ }^{53}$

One of the basic principles of today's society is that a free and a well-functioning market is the most efficient way to operate the economy. There, however, are exceptions to this rule and in some cases, government intervention in the economy is necessary to make up for the market's failure to bring about the most optimal allocation of resources. ${ }^{54}$ The reasons for this are generally recognized as the following four: market power, incomplete information, externalities and public good. In terms of energy, and electricity in particular, the last two factors are of particular interest. Externality refers to "a cost or benefit that is ignored by the market in the determination of prices," 55 and goods or services have public good characteristics if "once they are created they all are available to all consumers and cannot be withheld from one individual without withholding them for all." $" 56$ There are thus external costs and benefits that are not present in the internalized market decisions m eaning that reallocation of resources could achieve a higher level of public welfare. In regards to security of electricity supply, it is justified for the government or the system regulator to guarantee supply through reserve capacity. Without these measures, the market may tend to produce a level of energy security that is less than optimal from the society's point of view. Market regulation is thus needed, but the extent of regulation depends on political decisions. Regulation, however, can have a pivotal effect on electricity markets because electricity has an unusual nature compared to most other commodities. It is either impossible or uneconomical to store. Once produced, electricity must be consumed. Also, its consumption is seasonal and even changes greatly from one day to the next. The wide use of electricity in society creates a low tolerance of supply failures as it a key input in all economic

\footnotetext{
${ }^{52}$ Haghighi 2008, p 463.

${ }^{53}$ Haghighi 2008, p 263.

${ }^{54}$ Malcolm Abbott, „Is The Security of Electricity Supply a Public Good?“ Electricity Journal 8(2001): 31

55 Bohi, Toman \& Walls 1996, p 2.

${ }^{56}$ Abbott 2001, p 32.
} 
processes. Because it is a secondary energy source, security of electricity supply depends on supply of other fuels, adequacy of production capacity and uninterrupted distribution to consumers. It is the production phase, however, that is subject to additional concerns. Because electricity is mostly generated domestically, the hazards connected to production, like general safety issues and environmental problems, are directly related to energy security. Or rather, concerns over these negative aspects of electricity generation can have a much larger influence over production capabilities and thus, security of supply. An example of this is emissions trading that can greatly affect competitiveness of polluting means of production.

The lack of supply of electricity is, on the other hand, seen as hurting a society's competitiveness in a world of societies and is thus perceived to be an existential threat. Electricity production that generates pollution is thus subject to a political compromise between the environment and security of supply. The most common definition of energy security is mainly concerned with availability of primary energy sources but it tends to exclude political aspects. Janusz Bielecki says that energy security is commonly defined as "reliable and adequate supply of energy at reasonable prices." $" 57$ Bielecki explains that reliable and adequate supply means "uninterrupted supply that fully meets the needs of the global economy" and the interpretation of reasonable prices is perceived differently by energy producers and consumers but in general "it means that prices are cost- based and determined by the market based on supply/ demand balances." 58 It is the first part of the definition that tends to be problematic as it treats all economies the same way and does not take into account different economic environments. This is relevant in regards to electricity because it does not have a global market price and both its supply and the price are often dependent on legislation and regulation that may greatly differ between different countries. Thus, the way electricity is produced becomes important in a specific set of cases although it may not directly affect reliable or adequate supply. Specifically, cases in which electricity is traded between two states with significantly different standards, i.e. environmental, affect prices of electricity and thus competitiveness of the producers in the country with higher standards. But because electricity is relatively rarely traded in large quantities between two states, it seldom is included in discussion over energy security. In relation to EU, energy trade with third countries

\footnotetext{
${ }^{57}$ Janusz Bielecki, „Energy security: is the wolf at the door?“" The Quarterly Review of Economics and Finance 42 (2002): 237.

${ }^{58}$ Ibid., p 237.
} 
may be problematic as it may consequently lead to greater dependency on electricity supply that may in turn create other issues over the reliability of supply. It is essentially an issue of trust as solidarity between EU Member States in a time of crisis can generally be expected, but not to the same degree in relation to third states. Thus, extensive dependence on foreign energy supplies can be seen as a security threat, especially at a time of crisis. Examples from history, such as the 1972 OPEC oil embargo and the Russian- Ukrainian gas disputes of 2004 and 2007 support this view. Also, extensive pollution from emissions, mining or nuclear reactors may pose a different kind of risks that may relate to living standards and global warming.

Due to different perceptions, definitions of energy security may vary. EU Commission defines energy security as "the ability to ensure that future essential energy needs can be met, both by means of adequate domestic resources worked under economically acceptable conditions or maintained as strategic reserves and by calling upon accessible and stable external sources supplemented where appropriate by strategic stock." 59 Looking at specific countries' contemporary definitions, energy policy is, in the UK, Poland and France, required to firstly ensure security of supply with reasonable prices but is followed by additional objectives to do it in a technically and economically justified way including protection of the environment. ${ }^{60}$ The UK perhaps goes furthest by emphasizing acceleration of the transition to a low carbon economy. This is, however, understandable, as it has been setting the pace of EU energy market acceleration.

\subsection{Estonian perceptions of energy security}

The Estonian electricity system was constructed as a part of the Soviet Union's northwest electricity system. ${ }^{61}$ This synchronized system, called the IPS/UPS (intermittent current), currently includes Russia, Belarus, Latvia and Lithuania. This essentially means that in order for the current to stay at the designated rate required to provide sufficient power, electricity demand and supply have to be in balance. All the mentioned countries' electricity networks are thus interdependent. Specifically, Estonia's connections with Russia have the capacity of 1050MW (400MW throughput from the Russian side) and the connections with Latvia have the capacity of

\footnotetext{
${ }^{59}$ European Commission, Green Paper, 2006.

${ }^{60}$ Mihal Meidan, „Perceptions and Misperceptions of Energy Supply Security in Europe and the 'China Factor',“ in

Energy Security: Visions from Asia and Europe, ed. Antonio Marquina (New York: Palgrave Macmillan, 2008): 37.

${ }^{61}$ Estonian Energy Market Inspectorate, Report on the Estonian Electricity and Gas Markets (for the European Commission), (2006): 9.
} 
$750 \mathrm{MW} .{ }^{62}$ There is thus a circulation in the system that could cover the entire Estonian peak electricity demand. As of the end of 2006, Estonia also has a 350MW direct current connection (Estlink 1) with Finland and another connection (Estlink 2), with the capacity of 650MW is to be completed by $2014 .{ }^{63}$ For the time being, the Estlink connection is the only connection that the Baltic States have with other EU Member States. For this reason, the Baltic States are sometimes referred to as an energy island. Estlink 2 will however increase connectivity and connections between Lithuania and Poland as well as between Latvia and Sweden are being negotiated. This action is taken under the Baltic Energy Market Interconnection Plan (BEMIP), launched as at the initiative of Commission President Jose Manuel Barroso at the 2008 autumn European Council, aiming to fully integrate the Baltic States into the European energy market and to strengthen interconnections with their EU neighboring countries. ${ }^{64}$

Estonia has a very small electricity market that is relatively well connected with Russia, Latvia and, after 2015, with Finland. The small size of the market, however poses some difficulties for market liberalization, as it may not provide enough demand for a healthy competition, especially if it's accompanied by considerable changes in environmental standards. It is also argued that the liberalization of a small market can have negative consequences as there might be higher risks to investors, backlashes to the environment and energy- saving technologies, and negative influences on the electricity systems' security of supply. ${ }^{65}$ Thus, in an isolated small market situation, liberalization might not be feasible. Burinskiene and Rudzkis arrive at a similar conclusion arguing that the liberalization to the Lithuanian electricity market would be inefficient and the electricity price would be oriented towards the price of the most expensive and large producer so that only a small share of electricity could be traded on the free market. ${ }^{66}$

\footnotetext{
${ }^{62}$ Ibid., p 12.

${ }^{63}$ Estonian Energy Market Inspectorate, Report on the Estonian Electricity and Gas Markets (for the European Commission), (2009): 13.

${ }^{64}$ Basic information about the BEMIP and the related documents available at http://ec.europa.eu/energy/infrastructure/bemip_en.htm

${ }_{65}$ Anton Laur, Koidu Tenno and Sulev Soosaar, "Development of Electricity Markets- Options for Estonia," In Essays in Estonian Transformation Economics, ed. Ü. Ennuste and L. Wilder, 211- 244, (Tallinn: Estonian Istitute of Economics at TTÜ, 2005): 212.

${ }^{66}$ Burinskiene, Marija and Paulius Rudzkis, "Feasibility of the liberal electricity market under conditions of a small and imperfect market. The case of Lithuania," Technological and Economic Development of the Economy Report, (2010).URL:

http://www.thefreelibrary.com/Feasibility+of+the+liberal+electricity+market+under+conditions+of+a...a0241861721
} 
Efficient market liberalization would thus require cross border trading between states. For Estonia, this is possible with any state it has connections with. Of these states, only Russia has the capacity to significantly export electricity. It has, in fact, been exporting electricity to Finland and Latvia, which both do not have domestic supply capacities to cover the demand. Lithuania has been in a similar situation after the closure of the Ignalina Nuclear Power Plant in 2010. It is thus highly likely that Estonia will also start to import electricity from Russia as the market opens and the polluting generation capacities have to be suspended. It becomes even more likely when we look at the future of electricity prices. In 2009, the Estonian Ministry of Economic Affairs and Communications estimated the prices to rise between 55- 70\% in 2013 as determined by the Nord Pool electricity exchange. The opening of Estonian wholesale market in April 2009 was accompanied by a $30-40 \%$ rise in electricity prices for the industrial consumers. ${ }^{67}$ The CO2 quotas would harm the competitiveness of electricity production from oil shale to an extent that it would be economically unreasonable. ${ }^{68}$ Russian electricity producers, however, are not subject to the same environmental standards as the EU Member States are. The Russian domestic regulated price has thus been, on average, $50 \%$ cheaper than electricity in the Nordic Countries. ${ }^{69}$ The Russian producers would thus be motivated to sell electricity to the Estonian market where the price would be determined by the Nord Pool exchange, allowing them to profit considerably more than selling to domestic customers. It appears like a win- win situation as it is believed that a competitive market will decrease prices for the Estonian consumers. According to the European Environment Agency, the adjusted for purchasing power Estonian electricity price was indeed already the fourth lowest in $2007 .^{70}$ This result, however, had been achieved at the expense of environmental dumping as the environmental cost is not adequately reflected in the price.

The Estonian government, however, does not see it as a win- win situation as it is concerned over security issues. Russia is "geo- economic actor endowed with substantial oil and gas reserves" and its "energy policy has been methodically consolidated over the past decade, with its national

\footnotetext{
${ }^{67}$ Anna- Greta Tsahkna, „Euroopa Liidu liberaliseerimispoliitika mõju Eesti elektriturule (Impact of the European Union's liberalization policy to the Estonian electricity market), “'Master's thesis, University of Tartu, Department of Economics, 2010, hypothesis 2 on page 55.

${ }^{68}$ Einari Kisel, “Arengud Euroopa Liidu energeetikaalases seadusandluses (Developments in the European Union energy- related legislature)," presentation at the Alternatiivid ja valikud energeetikas (Alternatives and choices in energy policy) conference, hosted by the Eesti Jõujaamade ja Kaugkütte Ühing (the Estonian Power Plants and District Heating Association, 23- 24 April 2009.

${ }^{69}$ Ibid.

${ }^{70}$ European Environmental Agency, Indicator EN31: http://www.eea.europa.eu/data-and-maps/indicators/en31energy-prices
} 
gas, oil and pipeline companies steadily coming under government control, all effectively underwriting its national revival, local leverage and regional clout." ${ }^{, 11}$ The EU came to fully understand this after the 2005- 2006 Ukraine- Russia gas disputes that effectively reduced Gazprom deliveries to Hungary, Austria, Slovakia, Romania, France, Poland and Italy between 14- $40 \%$ during a particularly bitter winter. ${ }^{72}$ Similar disputes, though with lesser consequences, occurred between Russia and Belarus in 2004 and 2007.

The basic mechanism is that Russia provides energy sources at a substantially lower price hoping to buy loyalty or create dependence that will allow the Russian government to have a greater leverage over the target states' policies. The disputes with Ukraine and Belarus arose from the fact that Russia threatened to increase the energy prices to global market levels that are substantially higher than what the countries were used to, if certain political demands were not met. The poor Eastern European countries are not able to pay the higher price, which allows Russia to cut off energy supplies. This, in turn, is a concern for the EU, as the states in question are transit corridors for Russian- EU energy trade and their inability to pay the higher prices affect the EU's security of energy supplies. This is one of the main reasons why alternative pipelines, like Nord Stream and Nabucco, are being built.

This mechanism, however, does not affect Estonia as it is both directly connected to Russian energy sources through railways, pipelines and an electricity grid; and it is paying the market price for natural gas. The only disruption in energy deliveries from Russia occurred in the winter of 1992/1993. Despite of Russian politicians' threats, no interruptions in energy deliveries to Estonian domestic consumption have occurred since. ${ }^{73}$ One of the reasons for this may be that Estonia is relatively self- sufficient in terms of primary energy. On average, it imported below $30 \%$ of primary energy resources since $1995 .{ }^{74}$ It is fully dependent on Russian only in terms of gas, which has accounted for $7-17 \%$ of total Estonian primary energy consumption. ${ }^{75}$ Nevertheless, Russian political influence in trade is indisputable. It significantly limited transit with Estonia in response to the 2007 'Bronze Night' and with Latvia in response to its proposed

\footnotetext{
${ }^{71}$ Amelia Hadfield, "EU- Russia Energy Relations: Aggregation and Aggravation," Journal of Contemporary European Studies 16(2008): 232.

${ }^{72}$ Ibid., p 240.

${ }^{73}$ Andres Mäe, "Estonia's energy security and the European Union," Estonian Foreign Policy Yearbook (Tallinn: Estonian Foreign Policy Institute, 2007): 93.

${ }^{74}$ Ministry of Economic Affairs and Communications, Estonian Energy 1991- 2000 and 2007.

${ }^{75}$ Ibid.
} 
allegedly anti- Russian language bill in 1998. Another example is the 2005 Russian ban on Polish meat imports after accusing Poland of low veterinary standards, despite the fact that they were good enough for all EU Member States.

In terms of electricity, the list of government- controlled energy companies also includes Inter RAO (formerly RAO UES of Russia), "one of the world's largest energy holding companies, accounting for $70 \%$ of the energy production and one- third of heat supply in Russia." ${ }^{, 76}$ Martha Brill Olcott argues that RAO UES aggressively moved into Central Asia in the early 2000s and, like Gazprom, it "would like to use Central Asian Energy to serve European markets."77 Only instead of oil and gas, it aims to develop hydroelectric power in Kirgizstan and Tajikistan as it is calculated to be more economical than in Siberia. ${ }^{78}$ It is, however, unclear whether Inter RAO's dominant situation in the Estonian market would be a security issue. Andres Mäe lists "the globalization and openness of markets, the connection of Russia's companies with political power, their capability as suppliers, the instability of Russia's internal policy and the impact of energy production and transit on environment" as possible risks to Estonia. ${ }^{79}$ Even though Inter RAO is an enormous company by Estonian standards, it does not seem to be willing or even able to influence Estonian political decision- making. The Estonian market is regulated according to EU directives; starting from 2013, all trading will be conducted under the rules of the Nord Pool electricity market and the Estonian transmission system operator, OÜ Elering, is not legally unbundled from any electricity producers. Despite the fact that the Estonian market is small, Inter RAO can sell electricity at a higher price, thus making a bigger profit than in its operations in Russia. Thus, it seems unlikely for the Russian government to use possible Inter RAO's electricity imports to Estonia as a political tool.

The Russian electricity market has also seen its share of reforms in recent years. Since $1^{\text {st }}$ July 2008, RAO UES' competitive and monopolistic sectors are fully unbundled. On the same date, Inter RAO was formed. Since $1^{\text {st }}$ January 2011, the Russian government has stopped regulation

\footnotetext{
${ }^{76}$ Anatoly Chubais, "Final Stages in the Reform of RAO UES of Russia- Future Developments in the Russian Energy Market," In Handbook of Utility Management, ed. A. Bausch and B. Schwenker (Berlin: Springer, 2009): 683.

${ }^{77}$ Martha Brill Olcott, "The Great Powers in Central Asia," Current History (October 2005): 334.

${ }^{78}$ Ibid.

${ }^{79}$ Mäe 2007, p 94.
} 
of the electricity price for large consumers. ${ }^{80}$ Government control also is expected to be decreased by the removal of cabinet ministers from boards of energy companies in order to improve the investment climate. ${ }^{81}$ For Inter RAO, this means the withdrawal of Igor Sechin, also known as the Russian oil czar, from the company's Board. This move has, however, yet to occur. The company has also made large investments to commissioning new production capacities in 2006- $2010 .^{82}$ The general goal of these reforms is to build "a new market- based energy sector with new opportunities and new investors." 83

In 2007, the most important security policy documents reflected a perception of threat from Russia and its "energy weapon". In the Estonian European Union Policy 2007- 2011, the Government prioritizes transparent and rule- abiding energy cooperation with Russia. ${ }^{84}$ The document Principles of Estonian Security Policy states that "there is a [global] competition over energy resources in order to achieve political and economic power. States and international organizations aim to increase security of supply to ensure cover their energy demand. States endowed with energy resources aim to increase their influence as much as possible." 85 It also states that Russia, in addition to political and economic means, is prepared to use its military forces to achieve its goals. These means also include Russia using its energy resources "as a political and an economic tool in different spheres of international relations." 86

Against this backdrop, energy security is seen as an important part of Estonian economic development. Estonian energy security itself specifically consists of "security of supply, security of infrastructure, connectedness to other EU Member States' energy networks and diversity of energy sources." 87 The mission of the Estonian electricity sector, as stated in the Estonian Electricity Economy Development Plan is to "provide the citizens of Estonia with the supply of electricity that is continuous, sustainable and has a reasonable price." ${ }^{88}$ If it can be observed that the Estonian government is acting as a "foot dragger" or a "fence- sitter" in the electricity market

\footnotetext{
${ }^{80}$ Chubais 2009, p 684.

${ }^{81}$ Reuters, 30 March 2011, URL: http://www.reuters.com/article/2011/03/30/russia-medvedev-taxesidUSLDE72T1HC20110330

${ }^{82}$ Chubais 2009, p 492; However, the amount of decommissioned capacities over the same time it unknown

${ }^{83}$ Ibid., p 693.

${ }^{84}$ Government of Estonia, Estonian European Union Policy 2007- 2011 (2007): 39.

${ }^{85}$ Government of Estonia, Principles of Estonian Security Policy, (2007): 6.

${ }^{86}$ Ibid., p 7.

${ }^{87}$ Ibid., p 18.

${ }^{88}$ Estonian Electricity Economy Development Plan, Ministry of Economic Affairs and Communications, (2008): 24.
} 
liberalization process, it is reasonable to assume that this is because of concerns over energy security. As I have briefly shown, one of the outcomes of Europeanization of the Estonian electricity market is a substantial loss of competitiveness that may end electricity production from oil shale in Estonia. An alternative explanation may be that the government is concerned over a social crisis that may emerge from shutting down the oil shale industry in Ida- Viru County due to dramatically decreased competitiveness. I analyze this in the last section of the thesis.

Hypothesis 6: Estonia's opposition to Europeanization of the electricity sector is due to energy security concerns

Hypothesis 7: Estonia's opposition to Europeanization of the electricity sector is due to concerns over a possible social crisis in Ida- Viru County. 


\section{Historical legacy of the Estonian electricity sector}

The first industrial power plants were built to Estonia at the end of the $19^{\text {th }}$ and the start of the $20^{\text {th }}$ century. Electricity production developed hand in hand with the larger cities and industrial centers of Tallinn, Tartu, Narva, Pärnu and Kunda. ${ }^{89}$ Until 1918, hydro power was the main source of energy in Estonia. Oil shale, an organic- rich fine- grained sedimentary rock, started to be used as a fuel in industrial sectors, mainly in cement production, in July 1918. The fossil fuel is found abundantly in Estonia and can be relatively easily extracted, the increased use of it as a fuel is understandable. Electricity production from oil shale started in 1924. The first larger plant was built near Tallinn (11MW) in the 1930s, followed by the Kohtla- Järve (1949- 1967, 39MW) and Ahtme (1952- 1957, 20MW) plants. ${ }^{90}$ Production capacity was substantially increased with the construction of two of the world's largest power plants that use oil shale as a fuel to generate electricity and heat, near Narva. The Balti and Eesti power plants were built from 1956- 1966 and 1964- 1973, respectively. ${ }^{91}$ These two plants formed the core of Estonian energy production as they accounted for $92 \%$ of all installed generation capacity in Estonia (after 1982). ${ }^{92}$ They were built for the purposes of the growing industrial need of St. Petersburg and subsequently connected to the Russian Power grid. Thus, the power plants were of regional importance, exporting electricity not just to Russia but to Latvia and Lithuania, too. Electricity production peaked in 1980 (19,9 TWh) and has gradually been decreasing since then. ${ }^{93}$ In 1991, oil shale accounted for $56.3 \%$ of Estonian primary energy demand and covered $98 \%$ of fuels for electricity production (in 1996, but it is reasonable to say that the number did not differ more than a few percent in 1990).${ }^{94}$ Because Estonian production capacity was larger than domestic demand, 37\% of electricity was exported. ${ }^{95}$ In Estonia, the oil shale power plants provided energy for a relatively large industrial complex, consisting mainly of the chemical industry and textile manufacturing. The oil shale industry employed a large number of people in North Eastern Estonia. Many people were brought to Estonia to work for the complex from all around the

\footnotetext{
${ }^{89}$ Eesti Energia, Energeetika ajalugu, URL: https://www.energia.ee/c/document_library/get_file?uuid=3cbe8bd1611e-45a5-b6ed-4f69f69cbee1\&groupId=10187

${ }^{90}$ Veiderma, Mihkel, „Estonian Oil Shale- Resources and Usage,“ Oil Shale 20(2003): 300.

${ }^{91}$ Eesti Energua, Energeetika ajalugu.

${ }^{92}$ Ministry of Economic Affairs and Communications, Estonian Energy 1997, URL: http://www.mkm.ee/doc.php?1790

${ }^{93}$ Veiderma 2003, p 300.

${ }^{94}$ Ministry of Economic Affairs and Communications, Estonian Energy 1991- 2000, URL: http://www.mkm.ee/public/E_Energeetika_1991-2000.pdf

95 Ibid.
} 
Soviet Union. Narva and the other larger cities in the region like Jõhvi and Kohtla Järve, formerly consisting mostly of Estonian- speaking population, were mostly Russian- speaking by the 1980s. It is thus clear the oil shale industry was not just important for security of electricity and heat supply, but because it employed a large number of people, it was also socially important. In 2000, it accounted for 4\% of Estonian GDP and employed more than 7500 people $\left(12500\right.$ in $\left.1991^{96}\right) .{ }^{97}$ After regaining independence, the oil shale power plants guaranteed Estonia self- sufficient electricity supply at a moderate price. $^{98}$

On the negative side, oil shale is a relatively inefficient energy source with a yield ranging from 11,5-17\%, depending on the production process. ${ }^{99}$ Electricity production also comes with a great environmental cost. During the years under the Soviet regime, no attention was paid to environmental protection. ${ }^{100}$ Power plants accounted for about $72 \%$ of all $\mathrm{CO} 2$ emissions $(170,7$ t) (in 1991), accounted for $82 \%$ of all water consumption in Estonia in $2000^{101}$, and for $72 \%$ of waste (oil shale ash and semicoke) in the same year. ${ }^{102}$ Oils shale mining creates additional problems as it has disturbed $8,4 \%$ of the area of the Ida- Viru County, deeming it unlivable in the future. Mining is also accompanied by lowering of the water level and discharging of mine water to the surface water (this was stopped in 2000). ${ }^{103}$ The oil shale mining and electricity production both have a complicated impact on the surrounding landscapes, on their ecological state and matter cycling. The external cost of electricity production has been calculated to be about 3 Eurocent/kWh (2007) whereas the average price of electricity in Estonia was 0.06 Eurocent $/ \mathrm{kWh}$ in 1991 and has gradually increased to 6 Eurocent/kWh today. ${ }^{104}$ Total environmental taxation, in 2008, was 5 Eurocent $/ \mathrm{kWh}$. It is thus easy to see that it is Estonia's largest polluter and if stricter environmental standards would be imposed, electricity production would consequently have to invest in cleaner and more environmentally friendly techniques.

\footnotetext{
${ }^{96}$ Sirje Niitra, „Eesti Energia valmistub erastamiseks (Eesti Energia is preaparing for privatization),“ Eesti Päevaleht, 28 November 1997.

97 Anto Raukas, "Energy Crisis and Oil Shale Industry," Unpublished, (2010): 10.

${ }^{98}$ Veiderma 2003, p 300.

${ }^{99}$ Ibid., p 302.

${ }^{100}$ Raukas 2010, p 4.

${ }^{101}$ Mainly for cooling, ash transport and pumping of water trapped in mines.

${ }^{102}$ Ministry of Economic Affairs and Communications, Estonian Energy 1991- 2000, URL: http://www.mkm.ee/public/E_Energeetika_1991-2000.pdf

${ }_{103}$ Raukas 2010, p 7.

${ }^{104}$ Dalia Streimikeine, Inge Roos and Janis Rekis, "External cost of electricity generation in Baltic States," Renewable and Sustainable Energy Reviews, 2008; Ministry of Economic Affairs and Communications, Estonian Energy 1991- 2000, URL: http://www.mkm.ee/public/E_Energeetika_1991-2000.pdf
} 
However, it has to be said that after Estonia regained independence, the restructuring of the economy and economic relations resulted in significant decrease in industrial output: it was only $50,8 \%$ in 1994 compared to $1991 .{ }^{105}$ Electricity production in 1993 was only $60 \%$ of the 1991 levels and it has roughly stayed at that level to this day. Environmental harmfulness, percentagewise, has nevertheless stayed roughly at the same levels. Thus, a substantial change in environmental policy could still have a possible impact on security of electricity supply.

Despite the environmental costs, oil shale mining and electricity production have continued. This is because electricity, as discussed before, is a strategic commodity for the development of the economy. The continuation of production is thus vital even though it has other negative effects. In comparison, Estonia also boasts some of the largest deposit of phosphorite ore in all of Europe. Even though its exploitation is economically lucrative, the environmental cost would be enormous. ${ }^{106}$ The result would be possibly the pollution of some $40 \%$ of Estonia's water supply and increased air pollution through ore processing at the mine. ${ }^{107}$ The adoption of phosphorite would also have required "another large influx of immigrant labor into Estonia, yet another demographic threat to the native population." ${ }^{\text {"108 }}$ The environmental question created an unprecedented public debate in 1987, the so called "Phosphorite War", leading to demonstrations when Estonia was still under Soviet rule. It created a movement for change that arguably was one of the reasons behind Estonia's eventual independence. Many of the top politicians of the early 1990 were a part of that movement. The oil shale industry, however, had already established itself in Estonia, employing a large number of people and providing Estonia with self- sufficiency with electricity. At the time, Estonia was a poor country with no domestic capital to invest in the electricity sector. The people even struggled to pay for basic energy services like heat or electricity. The economic situation and political instability initially excluded any foreign investment. Thus, the politicians, even though holding environmental protection in high regard, did not have an alternative for oil shale to consider in the early 1990s.

\footnotetext{
105 Ministry of Economic Affairs and Communications, Estonian Energy 1991- 2000, URL: http://www.mkm.ee/public/E_Energeetika_1991-2000.pdf

${ }^{106}$ Matthew R. Auer, Restoring Cursed Earth: Appraising Environmental Policy Reforms in Eastern Europe and Russia, Rowman \& Littlefield (2005): chapter 5.

107 Toivo U. Raun, Estonia and the Estonians, Stanford: Hoover Institution Press (2001): 223.

108 Ibid., p 223.
} 


\section{Empirical findings and analysis: development of EU and Estonian energy policies}

\subsection{1- 1995: Early stages of EU and Estonian energy policies}

This section aims to give an overview of the early stages of EU and Estonian energy policies. I first discuss developments on the EU- level with the aim to establish a framework against which to compare developments in the Estonian domestic level. In the latter case, I first aim to explain the nature of the politico- economic environment. Then, assuming that the EU did not have a significant influence on Estonian energy policy, the goal is to compare general principles of longterm development of the electricity sector in EU and in Estonia. This will give us an idea of the similarities and differences of the aforementioned policies in terms of the logic of appropriateness. For in later stages, the EU had an increasing influence in terms of logic of consequences/ incentives in Estonian domestic politics.

\subsubsection{EU energy policy}

Even though one of the key reasons for European integration in the first place was the idea of peaceful utilization of energy resources, the EU lacked a common energy policy for a long time. We can start talking about reform in the electricity market from the formation of the European single market in 1987, with the Single Europe Act, that required EU Member States to "remove physical, fiscal and legal barriers to the free movement of goods, services, capital and labor within the EU. ${ }^{109}$ "Of all the economic sectors enjoying some form of state- sanctioned monopolistic protection, the energy sector, and specifically the electric energy sector, has been the last one forced to liberalize." 110 The Single Europe Act provided a framework for reform in the electricity market but did not lead to liberalization. A proposal was made by the European Commission to impose an EU- wide carbon energy tax, but if failed due to opposition from the Member States, who perceived state autonomy on taxing as a core value, and from industry lobbies. ${ }^{111}$ As Frank Convery argues, because of unacceptability of taxation, this would eventually lead to an emissions trading scheme.

\footnotetext{
${ }^{109}$ Roberto J. Serrallés, "Electric energy restructuring in the European Union: Integration, subsidiarity and the challenge of harmonization," Energy Policy 34(2006): 2542.

${ }^{110}$ Ibid., p 2542.

${ }^{111}$ Frank J. Convery, „Origins and the development of EU ETS,“ Environmental and Resource Economics 43(2009): 392- 393.
} 
Some decisions, however, had already been made on environmental policy. Following the 1972 Stockholm United Nations Conference on the Human Environment, the EU adopted the 1973 First Community Action Programme on the Environment that outlined the Community's environmental mandate. It included "the improvement of Community living standards to provide clean air, pure water and food; access to nature as uncontaminated as possible; the elimination of distortions in competition and technical barriers to trade due to differences between national environmental legislation; the regulation of pollution that crosses national boundaries." ${ }^{112}$ A step further was the 1984 Directive on combating air pollution from industrial plants (84/360/EEC), but it only dealt more with distortions in competition and technical barriers to trade. ${ }^{113}$ Emissions from industrial plants, believed to cause acid rains, were addressed four years later, in the 1988 Large Combustion Plants Directive (88/609/EEC), aiming to reduce sulphur dioxide, oxides of nitrogen and dust emissions. Talks over the adoption and the content of the Directive went on for five years because of opposition from Italy, Ireland, Portugal, Greece, Spain and the UK. ${ }^{114}$

The EU environment policy thus did not have an easy beginning. The Member States' energy sectors were considered national issues and the Commission had a difficult time increasing its power in these sectors. A failed carbon tax and the lengthy negotiations over including energy in the Single Europe Act framework show a strong opposition from the Member States. First steps, however, had already been taken, i.e. with the industrial plants directive in 1984.

\subsubsection{Estonian energy policy}

After regaining independence in 1991, Estonia started to transform its economy from a centrally planned communist one to a capitalist market economy. The concept was to make the former Soviet republic economically independent (so- called self- subsistence or autarkic). ${ }^{115}$ A plan for the energy sector, suggestive by nature since it was written by scholars and was not an official government document, "Eesti energeetika arengukava aastani 2005" (Estonian energy development plan until 2005), had developed already in the late-1980s, setting the principal goals until 2005. Specifically, the main aims were to take the energy sector under government control, transform energy companies into for- profit competitive organizations, create a national

\footnotetext{
${ }^{112}$ Catherine A. Ramus, "The Large Combustion Plant Directive: An Analysis of European Environmental Policy," Oxford Institute of Energy Studies paper EV7 (1991):11.

${ }^{113}$ Ibid., p 1.

${ }^{114}$ Ibid., p 28.

${ }^{115}$ Estonian Ministry of Economic Affairs and Communications, “Estonian Energy 1991- 2000,” (2001): 1.
} 
energy development plan, construct a gas- turbine power station to cover peak consumption, support small energy companies for diversification purposes, not to renovate the old Balti Power Plant, not to allow the construction of a new oil shale mine and an oil shale Viru Power Plant as it was stated that the current production capacities would be sufficient until 2005- $2010 .{ }^{116}$ The relevancy and correctness of these principles have been subsequently confirmed by state officials. The first official guidelines were given by the document "Eesti energeetika arengu üldpõhimõtted aastani 2003" (General principles in the development of Estonian energy until 2003), outlining three future development phases: 1) development of a legal basis and the creation of economic relations, 2) increase in energy efficiency and the development of price and tax policies, and 3 ) the integration and functioning of a regional energy complex. ${ }^{117}$

At first the government took all enterprises operating in the energy sector under its administration, setting up state- owned companies starting from $15^{\text {th }}$ January and $10^{\text {th }}$ April 1991. ${ }^{118}$ The production associations "Eesti Põlevkivi" (Estonian Oil Shale) and "Eesti Energia" (Estonian Energy) were turned into a state- owned consortium RAS Eesti Energia starting on 1 January 1993, along with the transmission system operator "OÜ Põhivõrk" and several distribution network enterprises. The first restructuring processes occurred with the separation of small district heating companies from the consortium by transferring ownership to the local authorities. $^{119}$

A privatization process of the state- owned companies started with the establishment of the stateowned company "Eesti Erastamisettevõte" (Estonian Privatization Company) in 1992 that would coordinate the privatization process. ${ }^{120}$ Privatization in the electricity sector, however, would only involve a few distribution network companies.

The Estonian government listed a number of companies, agencies and organizations that are vital for the uninterrupted functioning of the country's economy in 1991. That list included the production associations "Eesti Põlevkivi" and "Eesti Energia". Thus, the government saw these two organizations to be of foremost importance not just in ensuring the security of supply of

\footnotetext{
${ }^{116}$ Ibid., p 86.

${ }^{117}$ Ibid., p 86.

118 Riigi Teataja (Official Journal of Estonia), RT 1991, 2, 21 and RT 1991, 14, 204.

${ }^{119}$ Sirje Niitra, „Eesti Energia valmistub erastamiseks (Eesti Energia is preparing for privatization),“Eesti Päevaleht, 28 November 1997.

${ }^{120}$ RT 1992, 41, 544.
} 
electricity but for the development of the entire economy. The energy sector was regulated by the Eesti Vabariigi Riiklik Energiaamet (Estonian State Energy Agency), created in $1991^{121}$ and responsible for shaping Estonian energy policy, price formulation and the development of future ownership structure, and market regulation for the energy sector. ${ }^{122}$ The agency, however, was reorganized under the Ministry of Economic Affairs and ceased to exist as an autonomous entity. $^{123}$

Initial regulation over supply of primary energy resources, supply of electricity and environmental protection for the next four years was formulated by the Republic of Estonia's Supreme Council in 1992. ${ }^{124}$ It set the limits of oil shale mining and electricity generation as well as emission goals to honor the 1979 Geneva Convention on long- range transboundary air pollution by aiming to reduce SO2 emissions by 50\% in 1995 compared to 1980 levels. This goal appears extremely ambitious, but the numbers are deceiving. Because of the lack of attention to environmental issues by the Soviet Union, SO2 emissions in Estonia in 1980 were 274800 tons whereas the number had decreased to 179200 tons by 1992. As a result of the restructuring and reorienting the Estonian economy after regaining independence, its size was rapidly shrinking. Thus, reduction of SO2 emissions from 274800 tons to 110300 tons in 1995 was not as difficult to achieve as it might appear. ${ }^{125}$ Additionally, oil shale mining and electricity production was to decrease on average by $6.5 \%$ over the next four years. Another regulation was issued by the Estonian Government to determine the price of oil shale and environmental taxes. The average selling price of oil shale was to be 16.1 rubles per ton (the Estonian kroon was not yet introduced) (which is app. 0.50 USD in 2010 value) and the mining company was to pay 8 million rubles of environmental taxes (of which 3 million was emissions tax and 5 million natural resources tax) (which is app. 0.0125 USD in 2010 value per ton). ${ }^{126}$ This was the price that buyers, i.e. the electricity and chemical companies, had to pay Eesti Põlevkivi, but the mining company did not

${ }^{121}$ RT 1991, 32, 406.

${ }^{122}$ RT 1992, 6, 98 .

${ }^{123}$ RT 1994, 40, 1366.

${ }^{124}$ RT 1991, 22, 259.

${ }^{125}$ See second table in RT I 2005, 58, 462, URL: https://www.riigiteataja.ee/akt/955023

${ }^{126}$ RT 1991, 4, 69. 
have to pay for the mining rights. After 1991, the prices would be regulated by the Estonian Pricing Agency that was also to be responsible for the price of electricity. ${ }^{127}$

The electricity sector thus remained owned by the state and the most fundamental criteriaproduction volumes and prices- were centrally planned to meet the needs of an economy in transition. For the time frame of 1991- 1995, no significant changes, i.e. direction towards a market economy, were planned. A major change was environmental protection, aiming to decrease emissions and to tax mining for environmental reasons. Compared to modern standards, environmental issues were addressed only to a small degree. This is, however, understandable for a newly independent country. Discussions in the parliament show that environmental issues were of the least concern as it was uncertain how to provide essential services and commodities, like heat and electricity, to the people who were often unable to pay for them. Thus a market economy in the energy sector was, at the time, out of the question.

As we can see, the EU's and Estonian energy policies were incomparable in this period. Estonia was implementing shock- economics in the early 1990s and underwent a massive economic transformation that decreased industrial output by $40 \%$ over four years. The first priority was to stabilize the economy and environmental protection as well as investments to the power generation and distribution infrastructure was out of the question due to the lack of resources. However, principles like market economy and greater environmental protection were prioritized. The unofficial development plan, written by scholars, can even be interpreted as radical compared to EU policies. The reality of the Estonian economy, however, greatly limited Estonian ambitions. Fundamental economic transformation requires political and economic stability as a precondition and Estonia needed more time to implement the changes to a greater degree.

Hence, there was a misfit due to historical legacies, deeming hypothesis 2 (historical legacies influence domestic politics) correct. Of course, other factors have had an influence on the situation, too. They will be discussed in the coming chapters.

\subsection{5- 2004: Estonia as an EU candidate state}

In this period, the main focus of research is on the mechanisms of Europeanization during Estonia's status as a candidate state. First, a brief overview of the beginning of the accession

${ }^{127}$ RT 1992, 28, 390. 
negotiation process is given. Then, I will give an overview of developments in EU energy policy that essentially also constitutes the energy acquis. Compared to the earlier period, adoption of EU legislation was now a precondition to accession. In this context, I will aim to evaluate the EU's use of conditionality. In particular, how much room for interpretation was left for Estonia to implement change?

\subsubsection{Estonia and the $\mathbf{E U}$}

The first steps towards European Union membership by Estonia, Latvia and Lithuania were taken $12^{\text {th }}$ June 1995 when the three states signed association treaties with the EU (European Treaty), six months after Austria, Finland and Sweden became EU members. An official application for accession was presented to the EU on $28^{\text {th }}$ of November the same year. The European Council decided to start official accession talks on $13^{\text {th }}$ of December 1997 at the Luxembourg European Council. The two other Baltic States were not initially part of this decision showing that Estonia had been more successful in adopting different criteria for accession. ${ }^{128}$

The European Treaty aimed to liberalize trade between the EU and Estonia and called for greater scientific, educational, cultural and environmental cooperation. ${ }^{129}$ The accession talks, however, required Estonia to adopt EU principles that in practice meant a great change in legislation. This process had in fact started before than the actual talks began for it was well known that Estonia had to make major changes to its legislature to meet the membership criteria formulated at the 1993 Copenhagen European Council.

\subsubsection{EU energy policy}

The EU agreed to liberalize its electricity markets in 1996, after eight years of controversial negotiations. ${ }^{130}$ The European electricity markets had typically been dominated by regional or national monopolies. Several attempts to establish a supranational energy policy had failed because "member states have been keen to retain tight control over a sector that they consider to be of strategic political and economic importance."131 In Europe, this situation started to change

\footnotetext{
${ }^{128}$ All dates from Riigikogu, "Eesti eurointegratsiooni kronoloogia (Chronology of Estonian integration to the EU)," Riigikogu home page, URL: http://www.riigikogu.ee/index.php?id=33212

129 Streiman, Alar, "Eesti ja Euroopa Liit (Estonia and the EU)," Yearbook 2001, Estonian Ministry of Foreign Affairs (2002), URL: http://www.vm.ee/?q=node/4159

${ }^{130}$ Rainer Eising, „Policy Learning in Embedded Negotiations: Explaining EU Electricity Liberalization,“ International Organization, 56(2002): 85.

${ }^{131}$ Burkard Eberlein, ,The Making of The European Energy Market: The Interplay of Governance and Government,“ Journal of Public Policy 28(2007): 75.
} 
in the early 1990s when United Kingdom and the Nordic Countries started to first adopt comprehensive electricity market reforms, influenced by a spillover effect from global privatization and liberalization, as Burkard Eberlein explains. ${ }^{132}$ A second development was connected the incremental incorporation of the energy sector to the single market agenda by the European Commission. The process was slow due to Member States' opposition and the Commission "opted for the negotiated decision route by the Council legislation." 133

A framework for EU energy policy was established by the 1995 Green Paper (94/659/EC) on energy policy, emphasizing the interrelation of three goals: environmental sustainability, security of supply and establishment of an internal market for energy.

The debates resulted in the First Electricity Directive in 1996 (96/92/EC). It "distinguishes the regulated segments of the industry (transmission and networks infrastructure) from the competitive segments (generation and supply or retail)." This distinction was to be the basis of the "gradual opening of the electricity market, establishing different rules concerning nondiscriminatory access to the transmission and system network, leaving it to the Member States to choose between third Party access (regulated or negotiated) and the single buyer model." It also "established requirements for settlement of national disputes indicating two options for the construction of new generation plants (by tender and authorization)" and "required the unbundling of the transmission system operators (TSOs), and the separation in accounting of transmission and distribution from other market actors." ${ }^{134}$

According to Pierre Bauby and Frédéric Varone, the Directive was the result of an intergovernmental compromise between France and Germany. ${ }^{135}$ They say that "it was directly negotiated between French President Chirac and German Chancellor Kohl, who were at odds over the degree of openness needed for electricity markets." "136 To increase the degree of competitiveness of German industry, Kohl, supported by the German industry lobby, wanted rapid and broad liberalization. The French, on the other hand, were satisfied with the current

\footnotetext{
132 Ibid., p 75.

${ }^{133}$ Ibid., p 76.

${ }^{134}$ Fabio Domanico, „Liberalization of the European Electricity Industry: Internal Market or National Champions,“ Worldenergy.org (2007).

${ }^{135}$ Pierre Bauby and Frédéric Varone, "Europeanization of the French electricity policy: four paradoxes," Journal of European Public Policy 14(2007): 1050.

${ }^{136}$ Ibid., p 1050.
} 
situation and wanted to maintain limited liberalization. The French industry also wanted to "keep its advantages in regard to its technological expertise and its nuclear industry, as well as to be able to continue to support a policy of regional solidarity."137 The German position, however, received more support in the EU, "and the French government agreed to start opening its market in hope of profiting from EDF's competitiveness which resulted from the French nuclear programme." ${ }^{138}$ Thus, the Directive can be seen as driven by between French and German national objectives, rather than being concerned with promoting European objectives. ${ }^{139}$

This framework did not achieve expected results as "the negotiated Third Party access, the limited effect by accounting unbundling, duty and the lack of obligation to create national electricity regulators did not foster the achievement of competitive markets." ${ }^{140}$ Andres Pointvogl agrees with this saying that a move towards a single market was problematical because of reasons like "shortcomings in Member States' implementation, discriminatory market access or the dominance of incumbents." ${ }^{\prime 141}$ Eberlein sees in the whole process an unlikely outcome because of skeptical governments and the incumbent utilities being stronger than the pro- liberalization coalition of consumers and potential competitors. ${ }^{142}$ He also shows that the literature has given different explanations regarding theoutcome to this puzzle.

Security of supply issues were primarily tackled in the Directive 98/93/EC, regulating a minimum security stock of oil and petroleum products.

The environmental dimension was addressed by the Integrated Pollution Prevention and Control Directive (96/61/EC). Its main goal is to limit pollution to the level of best available techniques by regulating emissions in air, water and land by permits. The Directive has since been replaced by the Directive 2008/1/EC that mainly just simplifies the legislation and introduces linguistic changes but does not substantially change the original Directive. A key decision that aimed to reduce greenhouse gases was made in June 1998, when the Member States agreed to a national

\footnotetext{
${ }^{137}$ Ibid., p 1050.

138 Ibid., p 1050.

${ }^{139}$ Ibid., p 1050.

${ }^{140}$ Ibid., footnotes on p. 4.

${ }^{141}$ Andreas Pointvogl, "Perceptions, realities, concession- what is driving the integration of European Energy Policies," Energy Policy 37(2009): 5709.

${ }^{142}$ Eberlein 2007, p 76.
} 
target to reduce emissions by $8 \%$ compared to Kyoto targets of $1990 .{ }^{143}$ These goals were subsequently made legally binding. ${ }^{144}$ As Frank Convery argues, this decision was important in enabling the emergence of the Emissions Trading Scheme. ${ }^{145}$

The environmental sustainability dimension was further strengthened by the Directive 2001/77/EC, requiring Member States to "increase the share of green energy sources in the production of electricity to $22 \%$ by 2010 . It also requires Member States to promote investments in green power generation." 146 A slightly different approach was taken by the Large Combustion Plants Directive that was amended in 2001 (2001/80/EC). It aims to reduce emissions of acidifying pollutants, particles and ozone precursors (particularly SO2, NOx and dust) from large combustion plants of rated thermal input of equal or greater than $50 \mathrm{MW}$ for it is needed to combat acidification, eutrophication and ground- level ozone as part of the overall strategy to reduce air pollution. ${ }^{147}$

Because of the limited success of the First Electricity Directive, the Commission put forward new legislative proposals in 2001. A favorable political context allowed the Florence Forum ${ }^{148}$ to arrive to an agreement resulting in the 2003 Second Electricity Directive (2003/54/EC) and the Regulation 2004/1223/EC. Fabio Domanico explains that the Directive has four main objectives: "First, it guarantees better non- discriminatory access to the network, eliminating the possibility of negotiated third party access and allowing only the regulated TPA, assuring all market operators more rights to access the network. Second, it assures a more effective legal separation between market actors and the operators working in the transmission and distribution sectors, with the aim of limiting the risk of cross subsidization and discrimination between incumbents and new entrants. Third, it establishes the obligation for Member States to create an effective regulator with a major degree of independence from market operators but not from national governments. Fourth, theDirective provides a timetable for the different market opening stages, giving consumers freedom of choice over suppliers. [The deadlines for opening stages are] $1^{\text {st }}$

\footnotetext{
${ }^{143}$ Council conclusions of 16- 17 June 1998, Council Doc 9702/98.

${ }^{144}$ Convery 2009, p 399.

145 Convery 2009.

${ }^{146}$ Domanico, p 6.

${ }^{147}$ Summary and documentation available at: http://ec.europa.eu/environment/air/pollutants/stationary/lcp.htm

${ }^{148}$ An informal biannual meeting, set up by the Commission in 1998, of important market actors and stakeholders to discuss regulatory propositions. The Forum is chaired by the Commission and the Member State holding the EU presidency. Now located in Rome.
} 
July 2004 for non- domestic users (industrial, commercial and professional consumers) and $1^{\text {st }}$ July for all consumers." 149 The Regulation oversees the "harmonized principles for tariff and payments between TSOs,"..."rules and compulsory guidelines regarding the management of network congestion and the allocation of cross- border capacity" and "provides rules about incentives for private investments in the network."

The common rules, however, still allowed "considerable scope for diversity in implementation by member states," for full harmonization, delegation of formal regulatory powers to the Commission or the establishment of an independent EU energy regulator was politically not an option. ${ }^{151}$ Failure to establish a pan- European regulator has been seen as the greatest weakness of the second set of energy directives." 152

The second energy package was followed by legislation emphasizing environmental sustainability. European emissions trading, separate from the Kyoto emissions trading, was first introduced by the Directive 2003/87/EC, that resulted in the European Greenhouse Gas Emissions Trading Scheme (started $1^{\text {st }}$ January 2005), allowing the more efficient producers in terms of greenhouse gas emissions to "sell their excess allowances to other more polluting ones," thus providing incentives to increase competitiveness by investing into more environmentally efficient methods of production. ${ }^{153}$ The goal is thus to reduce industrial greenhouse gas emissions in a cost- effective way. The Directive 2004/8/EC regarding the promotion of cogeneration is another example of prioritizing more sustainable power generation by allowing advantages in network access. ${ }^{154}$

Security of supply measures are were mainly regulated by the Directive 2005/89/EC, that requires the transmission system operators to guarantee an adequate level of generation capacity by maintaining reserve capacity and interconnectedness to other Member States' transmission networks, maintaining balance of supply and demand by the establishment of wholesale markets and by ensuring network investment by the companies in order to meet foreseeable demand for the market.

\footnotetext{
${ }^{149}$ Dominico, footnotes on p. 5.

${ }^{150}$ Ibid, footnotes on p. 5.

${ }^{151}$ Eberlein 2007, p 82.

152 Pointvogl 2009, p. 5709.

${ }^{153}$ Dominico, p. 6.

${ }^{154}$ Ibid, footnotes on p. 6.
} 
This shows us that the EU's energy policy had made some progress, but its implementation in Member States did not achieve the level that was hoped for. The trinity of security of supply, creation of an internal market and environmental sustainability had all been addressed but the legislation still allowed some wiggle room. Generally, security of supply had already been a priority for the Member States, but it was the latter two of the Commission's policy directions that faced some opposition. Emissions reductions were limited mainly to large industrial plants, but decisions on the Emissions Trading Scheme had been already made. In regards to the internal market, the main deficiencies in implementation were equal market access, unbundling of different electricity production and distribution related activities and connections between Member States. A general framework was nevertheless in place that both indicated the greatest problems and allowed for improvement.

\subsubsection{Estonian energy policy}

The Estonian association treaty with the EU started a wave of legislative reforms to update regulation in accordance with EU legislation. The first major step in terms of the energy sector regulation was the adoption of the Energy Act (Energiaseadus). Its first draft had already been made in 1992, but it did not make it into Riigikogu (the Parliament) for reading. The Ministry of Economic Affairs had, however, been working on improving it, involving domestic, EU and other international specialists, scientists and practitioners in the process. It seems, though, that the association treaty created a sense of urgency, along with the developments in the EU legislation in 1996.

It was recognized that the state of the Estonian energy sector was typical for a transforming country that was not up to the modern quality, safety and technical standards. The principal goal was to reorganize the energy sector, creating a framework for the implementation of safety, quality and environmental requirements. ${ }^{155}$ The Act aimed to create an energy market that would have price formation according to the balance between supply and demand, while ensuring the equal treatment of consumers in a monopolistic market and creating of a regulatory agency that would oversee the technical and price formation aspects of the market. It also created a foundation for the privatization of the power generation facilities.

\footnotetext{
${ }^{155}$ Opening speech of the Minister of Roads and Communications Raivo Vare in the first reading of the Energy Act in Riigikogu, $15^{\text {th }}$ January 1997, shorthand report.
} 
The Act was adopted in accordance of the developments in EU legislation, but it was based on the strategic principles stated in the Estonian Government's Fuel- and energy economy long term development plan (FEEDP), adopted in 1997, and was influenced by the 1994 Energy Charter that Estonia was to ratify after the adoption of the Energy Act. The FEEDP is of particular interest as it states the main policy goals in terms of energy. The document clearly states that energy policy is part of a grander plan to join the EU. Thus, the aim of Estonian energy policy, in part, must be in compatibility with the goals and legislation of EU energy policy.

The EU regarded the most important instruments in harmonizing Member States' and other European states' energy policies to be the liberalization of the market, price transparency of the price, efficiency in energy production and consumption, and the development of transnational energy networks. ${ }^{156}$ The Estonian specific energy policy goals were to be consistent with this framework. The main aims could be summarized as ensuring political and economic independence through security of supply in order to ensure economic growth required to join the EU; optimal prices, environmental protection, sustainable development and energy efficiency, and meeting the requirements for successful accession to the EU. The electricity specific goals were to increase the reliability of the electricity system, increasing the quality of electricity, and the optimal functioning and development of the electricity system. These goals were to be achieved through implementing market economy principles in the system of management and creating a system control center, and changing the frequency of the system to be compatible with the Western European ones as well as preparing the construction of an underwater electricity cable between Finland and Estonia.

The Energy Act had three main consequences, additional to the legal regulation regime. First, it established two regulatory agencies, Energiaturu Inspektsioon (Estonian Energy Market Inspectorate) $^{157}$ and Tehnilise Järelvalve Inspektsioon (Estonian Technical Surveillance Authority) $)^{158}$ in 1998. Both agencies were to be under the administration of the Ministry of Economic Affairs. The first was to be responsible the ensuring competition in the energy market (this was added in 2003), issuing operation permits, regulating the price of electricity and

\footnotetext{
${ }^{156}$ Ministry of Economic Affairs and Communications, Fuel-and energy economy long-term development plan, 1997.

${ }^{157}$ RTL 1998, 34, 181; RTL 2002, 23, 326.

${ }^{158}$ RTL 1997, 99, 589; RTL 2003, 24, 352.
} 
overseeing the market by the power vested in it by the law. The latter was primarily to conduct surveillance in technical fields.

Second, the Act allowed the restructuring of the oil shale complex. According to the Government Regulation No. 1277 (RT I 1999, 1, 23, 29.12. 1998), RE Eesti Energia was to be transformed into a holding company that owned the stocks of the Eesti and Balti Power Plants as well as the stocks of Eesti Põlevkivi, the oils- shale mining company, and OÜ Põhivõrk, the transmission system operator. The restructuring was reviewed by the National Audit Office of Estonia, which saw no contradiction in Estonian laws, or decisions previously made by Riigikogu or the Government. $^{159}$

Third, the restructuring created a heated debate over the privatization of the state- owned AS Eesti Energia that went on for six years. Privatization, part of the transition to a market economy in electricity production, was also seen to give foreign banks additional guarantees for loans needed to invest in renovating old and building new production facilities. The company was and still is of strategic importance politically and economically to Estonia. It is also Estonia's largest employer and is especially important in the northeastern mining and industrial region. Thus the privatization of the company was political in motivation.

A privatization plan was confirmed by the Estonian Government in December 1997. The stateowned company RAS Eesti Energia was to be divided into different independently- run companies but still owned by the state. Most of the companies were to be established in 1998, including transmission system operators, technical support, and heat and electricity producers. ${ }^{160}$ Some structural changes were done already in 1996, when two heat plants and two construction support functions were separated from Eesti Energia. The primary goal for this process was to make the companies eligible for privatization. Eesti Energia, with its subsidiaries became an independently- run company in 1998. Smaller restructuring and privatization continued inside the company over the next two years. ${ }^{161}$

\footnotetext{
${ }^{159}$ National Audit Office of Estonia, press release, 12.04.2000, URL: http://www.riigikontroll.ee/Suhtedavalikkusega/Pressiteated/tabid/168/dnn_ctr557_Article_List_paginationDBContr olGetPage/2/dnn_ctr557_Article_List_yearSelectControlYear/2000/ItemId/354/amid/557/language/etEE/Default.aspx

${ }^{161}$ Ministry of Economic Affairs and Communications, Eesti energeetika 1991- 2000, p 60.
} 
The center of the debate was not privatization itself, but how it was done. An American company, NRG, showed interest in creating a joint company with the Estonian government in 1996. In March 1996, a Memorandum of Understanding (MoU) was signed in Washington by the two sides that would set a framework and a timetable for the negotiations even though three other companies were interested in participating in the privatization process. The general idea was to partly privatize Eesti Energia (the State would hold $51 \%$ of the shares after the deal) and the foreign investor would then invest (what would've been the largest foreign direct investment to Estonia then) in the new company. The first key step was to develop a business plan by July 1997. By that time, however, Estonia had already experienced a few unsuccessful privatization experiences that would serve as warning examples. ${ }^{162}$ It created skepticism in public opinion and put the Estonian politicians under pressure. The process was criticized by the Estonian press for lack of transparency and for not offering a public access to the privatization. ${ }^{163}$ Although the Government had signed an Oil Shale Restructuring Plan 2001- 2006 that established the privatization process, in practice, it was the MoU that essentially set the direction of the future of Estonian electricity production. This process received loud criticism from the environmentalists' camp who accused the Government of unconstitutional action because the Ministry of Economic Affairs and Communications that had developed the restructuring plan had not evaluated the environmental impact of the restructuring. However, environmental concern was only a part of the issue. The government was accused of keeping electricity prices artificially low while ignoring the environmental costs and giving Eesti Energia a monopolistic position in the market by guaranteeing it favorable conditions while not doing enough to create electricity connections to EU Member States. Although Estonia had been able to meet emissions criteria under the Kyoto protocol, it was not because of increased efficiency but because of the decline of industrial output after regaining independence. Thus, the 1990 emission levels were relatively easy to meet as the economy had shrunk by $40 \%$ by 1995 , as noted before. The environmentalists pointed out that although international agreements were honored, Estonia was still one of the larger polluters in the world. Thus, the cynical treatment of the Kyoto criteria was not ethical. ${ }^{164}$

\footnotetext{
${ }^{162}$ First reading of the Energy Act in Riigikogu, shorthand report.

${ }^{163}$ Editorial, "Elektrijaamad konkursile," Äripäev, 6 November 1997.

${ }^{164}$ Riigikogu, Otsuse "AS Narva Elektrijaamad erastamisest” eelnõu (829 OE) arutelu jätkamine (Continuing the discussion over the decision "about the privatization of AS Narva ELektijaamad"), shorthand report:
} 
This discussion was in response to the Prime Minister Mart Laar's earlier presentation in the Riigikogu on 23 August 2001. He had assured that the negotiations with NRG were going as planned and it was in accordance with desirable developments. It appears that the wide criticism had had at least some effect as Laar announced that the Estonian government would withdraw from selling the minority shares of Eesti Energia, scheduled for 8 January 2002. He stated that the main reason was the improved economic situation of Estonia where the company would be able to invest and modernize the plants by itself. ${ }^{165}$ Another reason was that the American company could not present guarantees for a loan meant to finance the investments agreed upon in the MoU as it was expecting a guarantee from the Estonian state that it did not receive. According to one Estonian official, the decision was entirely political as the actual decision would have had to be made by the next government, something that the sitting government would have not tolerated. ${ }^{166}$

The failure to incorporate foreign investment to Eesti Energia did not inhibit development. Modernizing the power plants had, to an extent, already started in 1995, in the form of renovation of turbines, repairing of boilers, installation of new electrostatic precipitators and demolition of old combustion boilers. ${ }^{167}$ The installation of two CFB boilers ${ }^{168}$ had in fact started the same day in 2001 when Prime Minister Laar announced the deal with NRG was off. ${ }^{169}$

From the environmental point of view, the Energy Act was meant to be in accordance of the framework set by the 1995 Sustainable Development Act (Säästva Arengu Seadus, RT 1995, 31, 384). It was, in turn, based on the decisions of the UN Environment- and Development Conference (Rio de Janeiro, 1992). Electricity production was also affected by the Pollution Fee Act (Saastetasu Seadus, RT I 1999, 24, 361) that set fees for emissions to the air, land and water. Polluters in Narva, among other regions, had to pays of fee $20-50 \%$ higher than the normal rates $(\S 8,2.1$. and 2.2). The fees were initially relatively low, but were to rise remarkably over the next few years: CO2 from 46 kroon in 1999 to 137 in 2005 with similar growth rates on other emissions as well.

http://www.riigikogu.ee/index.php?op=steno\&stcommand=stenogramm\&day=12\&op $2=$ print $\&$ date $=1000195200 \& p$ kpkaupa $=1 \&$ paevakord=2000008040\#pk2000008040

165 “NRG- tehing oli ennas ammendanud," Postimees, 9 January 2002.

${ }^{166}$ Rafael Behr, Financial Times, 8 January 2002.

${ }^{167}$ Veiderma 2003, p 300.

$168215 \mathrm{MW}$ a piece, efficiency 32- 34\%.

${ }^{169}$ Veiderma 2003, p 300. 
Security of supply was addressed by delegating the obligation to ensure adequate supply to the transmission system operator by the Energy Act. At the time, Estonia was exporting electricity and additional measures were not seen as necessary. One of the main goals, however, was the establishment, as required by the EU, of strategic fuels reserves. ${ }^{170}$ Another action was the signing of the contract between Estonian, Finnish, Norwegian and US companies on 9 October 2001to build a 315MW power cable between Estonia and Finland. ${ }^{171}$ The cable was to start operation in 2004. It would then be the only power connection between the Baltic States and the EU.

In July 1997, the Commission expressed the view that Estonia did not face major difficulties "in approximating the energy related acquis in the medium term, provided that its current efforts were intensified." 172 Areas of specific importance were "the adjustment of monopolies including import and export issues, access to the network, energy pricing, State interventions, the restructuring of the oil- shale sector, emergency preparedness including building up mandatory oil stocks, energy efficiency and environmental norms." ${ }^{173}$ Some of these issues were addressed in either the Energy Act or other legislation. In fact, the Energy Act, as mentioned before, was formulated with the help of EU specialists and thus developed under EU supervision. A legal framework was thus in place, but further action was required, like adjustment of monopolies, access to networks, energy pricing, etc. Some of these deficiencies, like pricing and adjustment of monopolies, according to the Energy Act adoption discussion in the Parliament, were to be eliminated by 2000. The Commission's November 1998 and October 1999 Reports take notice of these deficiencies saying that "further efforts would be needed if Estonia were to participate in the internal energy market." 174 The November 2000 Report noted progress in restructuring of the oil sector, particularly by the selling of $49 \%$ of the shares of Eesti Energia to a strategic investor. As we know, this would not actually happen. The Report also noted that "considerable progress [was] still [to] be made in many areas, including security of supply, energy efficiency, etc., in

\footnotetext{
1701997 FEEDP.

${ }^{171}$ Kairi Kurm and Aleksei Gunter, "New power cable to unite Baltic and Scandinavian power supplies," The Baltic Times, 11 October 2001.

${ }^{172}$ European Commission, summary of Estonia's adoption of the energy related community acquis, available at: http://europa.eu/legislation_summaries/enlargement/2004_and_2007_enlargement/estonia/e14102_en.htm

173 Ibid.

174 Ibid.
} 
order to fully comply with the acquis in this field."175 The November 2001 Progress Report confirmed progress, notably in areas like adopting legislature and improving security of supply. It also pointed out the adoption of the Oil Shale Sector Restructuring Plan and gave an overview of the plan. However, further guarantees of its implementation were required. The Report also pointed out the labor intensive nature of the oil shale sector and "due to the tense socio- economic situation of the region [North- East Estonia] any reductions in the number of employees must be dealt with great responsibility." "176 The October 2002 Progress Report confirmed further progress towards harmonization with the acquis, particularly in terms of abolishing price distortions and opening up the gas market. It also reported on a major change in the Energy Act. It would be separated into sector- specific laws making regulation more precise and detailed. The electricity sector would then be regulated by the Electricity Market Act. ${ }^{177}$ The final Report was issued in 2003 saying that "Estonia was essentially meeting the commitments and requirements arising from the accession negotiations in the energy sector and was expected to be in position to implement the acquis by accession." "178 However, opening of the electricity market would not be done according to the requirements of EU directives but according to a schedule agreed during the negotiations. ${ }^{179}$

Before accession to the EU, Estonia still had to revise legislature regarding the electricity market, as was pointed out in the 2003 Estonian Progress Report to the Commission. The basic idea was to separate gas and electricity market regulation into two different, more precise and specific pieces of legislature. Liina Tõnisson, the Minister of Economic Affairs, Roads and Communications, justified the need for this change due to the quick development of the electricity markets. The Electricity Market Act proposal was in accordance with the Energy Act but had to take into account more recent developments, namely the adoption of the Directive on the Electricity Internal Market on the EU level. ${ }^{180}$ The main changes in the Electricity Market Act

\footnotetext{
175 Ibid.

${ }^{176}$ European Commission, Estonian Progress Report for the Commission Review, 2001.

${ }^{177}$ European Commission, Estonian Progress Report for the Commission Review, 2002.

${ }^{178}$ European Commission, summary of Estonia's adoption of the energy related community acquis.

${ }^{179}$ The decision for a transition period for the opening of the electricity market: http://eurlex.europa.eu/LexUriServ/LexUriServ.do?uri=COM:2007:0411:FIN:ET:HTML

A citation to the decision for a transition period regarding the Large Combustion Plants Directive can be found in the Oil Shale National Usage Development Plan 2008- 2015, on page 29:

http://www.envir.ee/orb.aw/class=file/action=preview/id=306730/P\%D5KKi+kinnitamine.pdf

${ }^{180}$ Tõnisson, Liina, opening speech in the first reading of the Electricity Market Proposal in Riigikogu in 23 October 2002, shorthand report.
} 
compared to the Energy Act, were the additions of both nuclear and renewable energy- specific regulation. A nuclear power plant could only be constructed upon the approval of Riigikogu ( $\$ 22$, 6). Regarding renewables, the main change was the obligation for the TSO to buy any electricity that is produced from renewable energy sources. This, however, concerns only a fraction of the electricity market as only $0.29 \%$ of all electricity in 2000 was produced from renewable sources. By 2006, the number had risen to $1.47 \%$ and the share of combined production from 0 to $10.7 \% .^{181}$ Oil shale still accounted for over $90 \%$ of all electricity production. It is also worth pointing out that the readings over the Energy Market Act proposal did not generate much discussion in the Riigikogu. During the three readings, only four questions were asked from the presenters. In comparison, during the Energy Act, at least ten questions were asked in every reading. It thus appears that the adoption of the Electricity Market Act was merely a formal procedure to fulfill requirements coming from EU directives and regulations.

As we can see, significant developments occurred in both the EU and Estonian levels during this period. Estonian energy policy generally followed the EU's lead, by adopting principles that were previously codified in the EU. Estonia was lagging behind in its energy policy and electricity market regulation. The major legislative changes were both required and advised by EU specialists. Both the Energy and Electricity Market Acts did take into account the situation in Estonia and the legislation was modified accordingly. In specific policy directions, energy security had already been ensured by the oil shale complex, but it wasn't until January 2002 when the implementation principle of best available techniques was started by renovating the $8^{\text {th }}$ energy bloc in the Eesti Power Plant. ${ }^{182}$ In terms of creating an internal energy market, actions were taken to harmonize the Estonian legislation according to EU requirements. Estlink 1, the power cable between Estonia and Finland would, however, be the only connection that the Baltic States would have with other EU Member States, although it was not built not as a part of an EU policy. If effect, an internal market in the Baltic States would, at the time, only be possible between the three states. Access to the market was still denied for third party- states, with a transition period negotiated until 2013. Changes in the environmental sustainability dimension were also rather cosmetic, with no serious action to reduce emissions from the Narva Power Plants.

\footnotetext{
${ }^{181}$ Estonian Ministry of Economic Affairs and Communications, Estonian Energy in Figures (2007): 19.

${ }^{182}$ Eesti Energia, Energeetika ajalugu.
} 
Support for electricity production from renewable resources was indeed granted, but the quantities were marginal without having any influence on the larger picture. Combined production can however be regarded as an exception in this context. The Estonian Government prioritized affordable and continuous electricity supply that would allow the Estonian economy to develop to a level required to join the EU. Thus, Estonia was still a transition country that, in principle, shared the same values as the EU, but the relative backwardness of the economy and historical legacies in the form of Soviet electricity infrastructure did not allow full adoption of the policies. Hence, hypothesis 4 is correct, as it can be argued that Europeanization has occurred because Estonia has been motivated by internalized identities, values and norms, and thus legitimacy of rules, appropriateness of behavior, persuasion and complex learning characterize the process of rule transfer and rule adoption in the Estonian electricity sector.

Because the Commission did not require full harmonization of the policies during Estonia's status as a candidate state, by allowing long transition periods, hypothesis 3 (Europeanization has occurred because of EU-s superior bargaining position that has led to an ability to threaten with noncooperation and thereby force to make Estonia concessions) is incorrect. It must also be recognized that restructuring an old and substandard electricity sector to modern levels may not even be possible in six to seven years. Concessions in demands are thus understandable.

Because of the historical legacy of the oil shale complex, the status of hypothesis 5 remains vague. Estonia had induced reforms that were similar to the European ones because they were seen as effective remedies of inherently domestic needs and policy challenges, but the process had started before accession talks with the EU began. It is thus not appropriate to call this process Europeanization. Rather, the background of the change is more profound, having global characteristics. It is also important to note that not all EU rules were recognized as effective remedies even by the Commission. Hence, the formulation of hypothesis 5 is not appropriate, at least in the short- term, to explain change in the case of the Estonian electricity sector.

The negotiated transition periods also mean that, in principal, the accession process continues even after Estonia joined the EU. But by granting membership to Estonia, EU agreed to give away a large part of its bargaining power (membership as the greatest incentive). After accession, Estonia was also able to participate in the decision making process and, at least in principle, has the opportunity to influence EU- wide policies. 


\subsection{4- 2011: Estonia as a new EU Member State}

In this period, the main focus of my research is to evaluate the success of Europeanization in the Estonian electricity sector. As in earlier periods, I will first give an overview of developments in EU energy policy to establish a framework in which to compare the Estonian policies. A more specific focus is on the conditions that either support or limit the process of Europeanization.

\subsubsection{EU energy policy}

The most important document concerning EU energy policy to date is the 2006 Commission of the European Communities Green Paper: A European Strategy for Sustainable Competitive and Secure Energy. It stated six priority areas: completing the internal European electricity and gas markets, an internal market that guarantees security of supply through solidarity between Member States, tackling security and competitiveness through a more sustainable, efficient and diverse energy mix, tackling climate change through an integrated approach, encouraging innovation through a strategic European energy technology plan, and aiming towards a more coherent external energy policy. ${ }^{183}$ Compared to the earlier policy directions, the 2006 Green Paper provides a more diverse framework by adding an integrated approach to tackle climate change and a coherent external energy policy to the agenda.

As a consequence of the Green Paper, a third energy and climate package of legislation was proposed by the Commission in January 2007 under the label an 'Energy Policy for Europe'. ${ }^{184}$ It was published in the Official Journal of European Union in August 2009 (electricity related were the Regulations 2009/713/EC and 2009/714/EC as well as Directive 2009/72/EC). The main aims are to establish an Agency for the Cooperation of Energy Regulators and to "better functioning of market access and competition by ownership unbundling or introducing independent system operators $^{185}$, for increasing regulators' capacities and for more transparency, aiming to draw the European model of energy market liberalization closer to the standard textbook model (Pointvogl's emphasis)." ${ }^{186}$ The package entered into force in September 2009, requiring implementation of the requirements by March 2011 and ownership unbundling by March 2012.

\footnotetext{
${ }^{183}$ European Commission, Green Paper: A European Strategy for Sustainable, Competitive and Secure Energy, 2006.

184 Eberlein 2007, p. 87.

185 According to the Directive, Member States can choose between ownership unbundling, legal unbundling (independent transmission operator) or an independent system operator.

${ }^{186}$ Pointvogl 2009, p. 5709.
} 
Recognizing its leading role in international climate protection, the EU aimed to further reduce its emissions at the Council of the European Union's Spring Summit in March 2007. ${ }^{187}$ Earlier European climate policy had been based in the United Nations Framework on Climate Change, and its Kyoto protocol that only run until 2012. To continue efforts of fighting global warming, the Member States' governments set the so- called 20-20-20 targets as a part of the third climate and energy package. The final legal texts were adopted by the EU's Council of Ministers in April 2009 . $^{188}$ Specifically, the goal was to achieve a $20 \%$ reduction of greenhouse gas emissions by 2020 compared to 1990 and an increase the share of renewable energy sources to $20 \%$ by the same year in the energy mix. It was also decided that the share of biofuels should rise to $10 \%$ of overall fuel consumption. The third 20 goal- reduction in primary energy use compared to projected levels, to be achieved by improving energy efficiency, was established in an energy efficiency communication from the Commission in $2008 .^{189}$

The package also revised the European Greenhouse Gas Trading Scheme that was originally divided into two phases. In the pilot phase (2005- 2007) the Member States could allocate $95 \%$ of the emissions to the polluting installations for free and for the second phase, $90 \%$ of the allowances would be free. ${ }^{190}$ In essence, the first period was to measure and verify emissions and to accumulate experience for further action. The idea is to gradually reduce allowances so that total emissions fall. The EU ETS works on the "cap and trade" principle. At the end of each year each company that falls under the criteria to be participating in the ETS must surrender enough allowances to cover all its emissions, or heavy fines are imposed. If a company is successful in reducing its emissions, it can sell the allowances to another company or keep them for future considerations. ${ }^{191}$ The key change in the second phase is reduction of emission allowances, but the basic principles are still the same. For the second phase, each Member State could propose national allowances, but it was for the Commission to decide the eventual cap allowed. ${ }^{192}$ The Directive 2003/87/EC was amended by the Directive 2009/29/EC (part of the third energy-

\footnotetext{
${ }^{187}$ Report of the Summit, p $12-13$ (http://register.consilium.europa.eu/pdf/en/07/st07/st07224-re01.en07.pdf)

${ }^{188}$ Council of Ministers, "Council adopts climate- energy legislative package," press release, URL: http://www.consilium.europa.eu/uedocs/cms_Data/docs/pressdata/en/misc/107136.pdf

${ }^{190}$ Emissions from the first phase were published in a Commission press release (http://europa.eu/rapid/pressReleasesAction.do?reference=IP/08/787\&format=HTML\&aged=0\&language=EN\&guiL anguage $=$ en)

${ }^{191}$ Emission Trading System at the European Commission home page (Emissions trading: EU-wide cap for 20082012).

${ }^{192}$ Commission press release (http://europa.eu/rapid/pressReleasesAction.do?reference=IP/07/1614)
} 
climate package) for the purpose of implementing a reduction commitment to meet the $20 \%$ overall reduction in greenhouse gas emissions for the third phase (2013-2020). It also lays down provisions to assess and implement a $30 \%$ reduction if other developed countries agree to honor the Kyoto protocol. An annual allocation quantity of allowances is to be decreased by a linear factor of $1.74 \%$. The greatest change for the third period is setting of an overall EU cap, with allowances then allocated to Member States and a move from allowances to auctioning (Article 10).

From the Estonian perspective, security of supply was most notably addressed by prioritizing an interconnection plan. The Commission subsequently launched the Baltic Energy Market Interconnection Plan (BEMIP) in the 2008 autumn European Council, with the goal of fully integrating the Baltic States into the European energy market and to strengthen interconnections with their EU neighboring countries. ${ }^{193}$ Specifically, the plan emphasizes interconnections between Estonia and Finland, Latvia and Sweden as well as Lithuania and Poland. So far, as noted above, it has resulted in beginning of construction of the Estlink 2 underwater power cable.

\subsubsection{Estonian energy policy}

By the time of the June 2001 Göteborg European Council meeting, Estonia had been able to provisionally close two- thirds of the negotiating chapters and it was decided that, among other states, it would be ready to join the EU in 2004. In the following years after joining the EU, no significant progress in Estonian energy policy can be observed, with the exception of minor amendments to existing legislation. In November 2005, the Estonian Government evaluated further changes that needed to be made to fully harmonize Estonian legislation with EU Directives. ${ }^{194}$ The Ministry of Economic Affairs and Communications still had to still adopt eight Directives, of which three were related to the electricity market or electricity production. In particular, the Electricity Market Act had to be amended in two parts and the third change was related to air protection.

It wasn't until 2008 when the Government adopted comprehensive energy- specific action plans. Estonia was facing substantial changes in the near future as the deadlines for market opening and

\footnotetext{
${ }^{193}$ Basic information about the BEMIP and the related documents available at http://ec.europa.eu/energy/infrastructure/bemip_en.htm

${ }^{194}$ Government of Estonia, the table can be found in the following link: http://www.valitsus.ee/UserFiles/valitsus/et/riigikantselei/euroopa/euroopa-liidu-oiguse-ulevotmine/direktiivideulevotmise-seis/koondtabel__dir_lev_tmine2.pdf
} 
implementing stricter environmental standards on electricity production were approaching. The most general guidelines for future action were envisaged in the Estonian National Energy Economy Development Plan until 2020 (ENEEDP) that set a general framework for the entire energy sector. ${ }^{195}$ Broadly, the need for adaptation of the Estonian electricity sector was influenced by global trends such as the "rise of global fuel prices, gradual liberalization of energy markets, start of the European Emissions Trading Scheme, deepening of energy supply problems, rise of energy security issues and developments in renewable energy."196 Furthermore, developments on the EU level such as the aim to reduce greenhouse gas emissions, increase of the share of renewable energy sources in energy consumption and efforts to decrease overall energy consumption required Estonia to honor the obligations it had taken with becoming an EU Member State. ${ }^{197}$ The development plan aims to ensure continuous, effective and sustainable energy supply at a reasonable price. ${ }^{198}$ These goals are to be achieved through diversification of the energy mix with connections to other Member States while maintaining a reliable transmission network; by increasing energy efficiency, through use of renewable energy sources and trough developing more environmentally friendly fossil fuels technologies; and by developing regulation that avoids price distortions and market position abuse. ${ }^{199}$ Additional sector- specific guidelines are specified in the respective development plans.

The Electricity Economy Development Plan 2008- 2018 reviews previous actions and sets new goals for the next policy period. It reports that the previous goals had been successfully achieved. In relation to the Narva Power Plants, two combustion boilers, using the new fluidized bed technology, had been installed in 2005. This investment, by far the largest in the Estonian energy sector since 1991, allowed significant reductions in fuel and water usage. It also reduced the amount of waste created in the combustion process and increased the boilers' energy efficiency. ${ }^{200}$ Strategic choices in the electricity sector were listed as follows: the need to decrease environmental cost of electricity production, obligations to decrease $\mathrm{CO} 2$ emissions in 2012 and 2016, need for more efficient use of oil shale resources, and the need to increase

\footnotetext{
${ }^{195}$ Ministry of Economic Affairs and Communications, Estonian National Energy Economy Development Plan until $2020,2008$.

${ }^{196}$ Ibid., p 3.

${ }^{197}$ Ibid., p 3.

${ }^{198}$ Ibid., p 31.

${ }^{199}$ Ibid., p 31.

${ }^{200}$ Ministry of Economic Affairs and Communications, Estonian Electricity Economy Development Plan until 2018, (2008): 8 .
} 
competitiveness of the Estonian electricity price due to the impact of emissions trading. ${ }^{201}$ Although after 2015 no energy source is to exceed a share of $50 \%$ in the Estonian energy mix, electricity produced from oil shale is still prioritized. Additionally, it has to be pointed out that the drastic decrease of electricity produced from oil shale is occurring because of higher environmental and technical standards required by the EU. Interestingly, the document does not discuss a situation where Estonia would not be able to cover its electricity demand by domestic production. As a study by Elering, the Estonian transmission system operator, reveals, Estonian electricity production will in 2016 decrease to the level where domestic supply is unable to cover approximately 20- $25 \%$ the peak consumption. ${ }^{202}$ By 2025 , if no additional generation capabilities will be built, the number will probably increase to almost $80 \%$. It remains unclear how the mission of the Estonian electricity sector- "to ensure the Estonian population with a continuous, sustainable energy supply with a reasonable price"- will be achieved if new production capacities will not be built. The measures to achieve continuous supply seem almost autarkic, with the exception of prioritizing of building a new interconnection with other states (Estlink 2). To support construction of new production capacities, government aid is seen as needed because "new power plants have never been built on open markets." ${ }^{203}$ It, however, does not propose creating more a favorable investment environment or using foreign policy tools, such as signing binding agreements with other states, to ensure security of supply in a context of an open electricity market. These are the questions on which Estonian politicians should be concentrating. ${ }^{204}$ The scope of the development plan is thus too narrow to take into account the reality of the Estonian electricity sector.

The Estonian National Oil Shale Usage Development Plan lists a large number of problems related to the sector, almost thirty pages overall. Estonian interest in regards to the sector is, however, to ensure "continuous supply of electricity and heating to the consumers with valued oils shale products while implementing best available techniques in mining and processing, using oils shale and its collateral natural resources effectively and with a minimum environmental and social cost in a way that ensures preservation of oils shale resources, security and the sustainable

\footnotetext{
${ }^{201}$ Ibid., p 16.

${ }^{202}$ OÜ Elering, "Eesti Elektrisüsteem varustuskindluse aruanne (Security of supply report of the Estonian electricity sector)," Tallinn (2010): 14.

203 Ibid., p 26-27.

${ }^{204}$ Andres Tropp, "Valed küsimused toodavad valesid vastuseid (Wrong questions produce wrong answers)," Eesti Energia Blog, 1 January 2011.
} 
development of the State." ${ }^{205}$ In order to achieve these goals, more effective, optimal and sustainable oils shale mining, processing and usage is prioritized as well as decreasing the social effects of activities and increasing research and development. Thus, oil shale is continuously seen as an essential part of the Estonian energy economy and electricity production.

Goals in terms of environmental sustainability have been set in the Estonian Environmental Strategy until 2030. In relation to energy production, the document sees the main problems in pollution concentration, great losses in electricity transmission, vulnerability of the electricity system in crisis- situations and in depressing of development of renewable resources. ${ }^{206}$ Since the goal of electricity production is to provide for Estonian consumption needs and to produce enough to be able to export electricity, no large reductions in emissions are foreseen. Diversifying energy sources and developing technologies with lesser environmental costs are aspired to, but by 2015 no reductions of absolute levels of greenhouse gas emissions are planned compared to 2005 levels. Diversification of the energy mix both in energy and electricity production is comparatively insubstantial as the share of oil shale is meant to be decreased by 10 percentage points, from $90 \%$ to $80 \% .^{207}$ Thus, the degree of environmental sustainability is dictated by the policy of security of supply. Substantially greater pollution reduction while ensuring security of supply would require restructuring the entire Estonian electricity sector. Interestingly, when pointing out the biggest problems to the health and life quality of the people, the document does not discuss the historical legacy of the oil shale industrial complex. Instead, the biggest problem is the legacy of the more recent past- "active economic activity that has been primarily concentrated on high profitability and the peoples' aspirations to achieve a living standard that is as high as possible." 208

Specific goals to increase environmental sustainability are described in the Environmental Action Plan 2007- 2013. ${ }^{209}$ In relation to energy, the main goals are to approve energy- related and environmental strategies, discussed above, in order to support and increase research and development as well as to increase the share of renewable energy sources in energy production

\footnotetext{
${ }^{205}$ Estonian Ministry of the Environment, Estonian National Oil Shale Usage Development Plan 2008- 2015, (2008): 32.

${ }^{206}$ Ministry of the Environment, Estonian Environmental Strategy until 2030, 2007: 22.

${ }^{207}$ Ibid., p 36.

${ }^{208}$ Ibid., p 26.

${ }^{209}$ Ministry of the Environment, Estonian Environmental Action Plan 2007- 2013, 2007
} 
and to renovate and build new capacities in existing oil shale power plants. In order to meet EU requirements (particularly the LCP and NEC Directives), the highest priority of action is given to the renovation of the Iru, Ahtme and Narva Power Plants in order to meet environmental requirements, as well as to build two new energy blocs to the Narva Power Plants. ${ }^{210}$ The decision to continue using oil shale as a fuel for electricity production has received criticism from the EU. Even though the new generation capacity is more efficient due to using improved technologies, it still generates high levels of emissions compared to most other methods. In one opinion, Estonia is planning pollution as oil shale is seen as a "dirty fuel" and the decision to build new capacities using oils shale as primary energy is undermining the EU's climate goals. ${ }^{211}$ From the Commission's standpoint, the problematic aspect in this issue is Estonia's aid to the energy company to finance the project. The Commission has not made a decision yet, but preliminary studies show that the government's support in the amount of 1.2 billion Estonian kroon (77 million euros) contradicts with the principles of free competition. ${ }^{212}$

One direct consequence of EU energy policy has been the legal unbundling of the Estonian transmission system operator. The company, formerly named AS Põhivõrk and part of the Eesti Energia, was bought by the government, put under the authority of Ministry of Economic Affairs and Communications, and renamed OÜ Elering. ${ }^{213}$ The move was required to ensure the transmission system operator's autonomy from production and retail related operations and to increase transparency and equal treatment in the electricity market. ${ }^{214}$ In March 2011, it was changed into a public holding company AS Elering. ${ }^{215}$ It remains under government control but is autonomous from energy producers. Elering is responsible for the effective and uninterrupted operation of the transmission system. In order to avoid supply failure in case of an accident, the company has started to construct a 126 million euro $250 \mathrm{MW}$ gas- fuelled reserve capacity power

\footnotetext{
${ }^{210}$ Ibid., p 38.

${ }^{211}$ Stephen Gardner, „Planning pollution in Estonia,“ The Digger blog, March 24, 2011, URL: http://blogs.euobserver.com/gardner/2011/03/24/planning-pollution-in-estonia/

$\frac{12}{212}$ The study is not public but it is referred to in this article: Mirko Ojakivi, ,Eesti Energia võib rivaalide kiusu tõttu rahata jääda (Eesti Energia might end up without the money due to rivals' obstinacy)," Eesti Päevaleht, 3 December 2010.

${ }^{213}$ Postimees Online, "Valitsus andis heakskiidu Eleringi ostuks (The government approves buying of Elering)," 27 August 2009.

${ }^{214}$ Ibid.

${ }^{215}$ Majandus.Delfi.ee, "Elering kujuneb umber aktsiaseltsiks (Elering becomes a public holding company)," 2 March 2011.
} 
plant in Kiisa, consisting of two energy blocs. The 150 and 100MW blocs should be operational in 2013 and 2014, respectively. ${ }^{216}$

As we can see, the development of the Estonian electricity sector until 2015 has generally occurred and been planned in accordance with EU laws and regulations. In all policy directions, the required legislative changes have been implemented. The reality, however, does not coincide with the legal framework. EU legislation has had a major impact on the Estonian electricity sector and will pose significant challenges in the future. Due to the negotiated transition periods, no major political decisions were required immediately after the accession to the EU. But the pressure to make a political decision over which direction Estonia should take in developing its energy sector is increasing as the transition periods' expiration dates are closing in. This has also meant that Estonian lobby in the Commission has been more active in negotiating exceptions. In general, the activity has concentrated on two issue areas.

First, in relation to the second phase of the Emissions Trading Scheme, Estonia and Poland contested the Commission's decision for the national emission quotas. For the period of 20082012, Estonia had requested a total of 24,38 million metric tons annually, albeit its verified emissions in 2005 had been 12,62 million tons. The Commission, after revising the requests, allowed emissions in the amount of 12,72 tons, slightly above the 2005 number. ${ }^{217}$ The Commission's decision was later annulled by the European Community's Court of First Instance by its 23 September 2009 decision, stating that the Commission had breached its powers. ${ }^{218}$ The issue currently remains unresolved as the Commission rejected the latest Estonian revised proposal in April 2011. ${ }^{219}$ The main reason behind the decision was that the quotas that Estonia planned to allocate to enterprises were too high. Form the Estonian standpoint, however, the Commissions quota policy is discriminating against them as its electricity sector exports a substantial amount of electricity to both Latvia and Lithuania, states which cannot meet their

\footnotetext{
${ }^{216}$ OÜ Elering, "Reserve power plant construction," Company home page, URL: http://www.elering.ee/reservjaamnr-1-ehitamine/

$\frac{}{217}$ Europa.eu, press release, "Emissions trading: EU- wide cap for 2008- 2012 set at 2.08 billion allowances after assessment of national plans for Bulgaria," URL:

http://europa.eu/rapid/pressReleasesAction.do?reference=IP/07/1614\&format=HTML\&language=EN

${ }^{218}$ Judgments of the Court of First Instance in the Case T- 183/07 and in Case T- 263/07, URL: http://curia.europa.eu/jcms/upload/docs/application/pdf/2009-09/cp090076en.pdf

${ }^{219}$ ERR (Estonian National Broadcasting), „Euroopa Komisjon lükkas tagasi Eesti heitmekvoodikava (European Commission reject Estonian emissions quota plan),“29 April 2011, URL: http://uudised.err.ee/index.php?06228046
} 
domestic electricity demand with domestic production. Consequently, Estonian energy companies don't know with how much free emission allocations they have at their disposal.

Secondly, in relation to market access, the government has lobbied for a more restrictive policy towards producers in states outside the EU. Due to principles in the Second Energy Package, Estonia will have to grant open access to its electricity market. Although the wholesale market (35\% of the market) has been already opened in April 2009 the retail market won't be opened until January 2013, as agreed upon in the accession negotiations with the EU. This effectively means that Russian producers have the opportunity to start trading on the Estonian market. Being subject to lower environmental and safety standards as well as not participating in the EU ETS, the Russian producers have a significant price advantage compared to European producers. Because of a higher electricity prices in the EU, and good interconnections with the Baltic States, it is likely that Russian companies will take advantage of the situation. In Estonia, this is seen as a situation of unfair competition and provides a basis for market failure. ${ }^{20}$ Anna- Greta Tsahkna's studied Estonian large- scale consumers' preferences on electricity price in relation to its origins and found that the cheapest price would be preferred, even if it originates from Russia. $^{221}$ In the case of equal prices, domestic electricity produces from renewable energy sources would, however, be their first choice. In a June 2008 discussion paper from Estonia to the EU, Estonia expressed concern over allowing producers in states outside the EU to access its electricity market. Due to a possible crucial impact it would have on the Baltic electricity markets, "it would be unacceptable to put Estonia's electricity supply in dependence on extensive electricity import from a third country, for example Russia."222 To eliminate Russian producers' competitive advantage, Estonia lobbied for measures that would include them in the ETS and make them subject to the same production standards as the producers in the EU. The aim was to ensure that substandard electricity imports from third countries "would not undermine the goals of the EU in fighting climate change, would not distort the competition in the internal EU electricity market and would not decrease the security of any member state." 223 The measures, however, contradict the principles of free trade. Also, concerns over competition distortion

\footnotetext{
${ }^{220}$ Susan Verheijen, „The Baltic States’ Electricity Policies. A Case Study of How the EU Influences the Baltic State Electricity Policies,“"Master's thesis, University of Tartu (2009): 71 - 72

${ }^{221}$ Tsahkna 2010, hypothesis 6 on page 56.

${ }^{222}$ Quoted in Verheijen 2009, p 71.

${ }^{223}$ Quoted in Verheijen 2009, p 72.
} 
caused by cheap electricity imports and over security were limited only to Estonia due to its small size, unique electricity system infrastructure and geographical position. For these reasons, it was difficult to gain support for the measures at the EU level.

Undermining climate change and competitiveness of EU industries, by increasing production costs is, however, a more common concern in the EU. The debate is characterized by the term carbon leakage, essentially meaning that "tighter controls on $\mathrm{CO} 2$ emissions in Europe will drive factories to relocate abroad," leading to a rise of greenhouse gas emissions in countries without emission reduction requirements. ${ }^{224}$ To address this issue, the Commission published a decision in December 2009, determining a list of sectors and subsectors which are deemed to be exposed to a significant risk of carbon leakage. ${ }^{225}$ Electricity production, however, was not included on this list, even though, according to one of the criteria, even "if the sum of direct and indirect additional costs induced by the implementation of Directive 2003/87/EC would lead to a particularly high increase of production costs, calculated as a proportion of the gross value added, of at least 30\%," i.e. Estonian oil shale- fired and Polish coal- fired power stations were to meet the criteria. ${ }^{226}$

The evolution of the debate can also be observed in the Estonian Energy Market Act. Its first version, adopted in July 2003, $\S 30(3)$ states that refusing a business permit to a producer or a (corporate) person in the Estonian electricity market may be allowed if it is based in a state that does not have the same standards on electricity buying, electricity imports, the environment, production costs, and in price formation. In February 2010, this provision was deleted from the Act due to its incompatibility with EU law. From January 2014, additional technical (3) and financial (4) provisions of cross- border transactions will be added to $\S 30$.

We can thus see how little power Estonia has over EU- wide policies, even if they are of crucial interest to it. The Commission's carbon leakage decision, however, demonstrates how exceptions can be made if an issue concerns more Member States, or in particular, larger Member States. Hence, Estonia is, in a sense, at the mercy of interests of the majority or more powerful actors in

\footnotetext{
${ }^{224}$ EurActiv.com, „EU industry and the 'carbon leakage' threat,“ URL: http://www.euractiv.com/en/climateenvironment/eu-industry-and-carbon-leakage-threat-linksdossier-188482

${ }^{225}$ Document C(2009) 10251, URL: http://eurlex.europa.eu/LexUriServ/LexUriServ.do?uri=OJ:L:2010:001:0010:0018:EN:PDF

${ }^{226} \mathrm{C}(2009) 10251,(5)$.
} 
the EU, even if an issue concerns its security. The example of Europeanization of the Estonian electricity sector thus demonstrates how Estonia, being a small state, may be greatly influenced by both unfavorable EU policies and Soviet infrastructural legacies.

A solution to securing accountability, transparency and reliability of imports form Russian producers has been achieved through a non- EU initiative: by joining the Nord Pool electricity exchange. Its rules do not make the Russian producers subject to higher environmental standards but the security advantage in joining the exchange lies in the fact that a supply failure to one state will undermine the reliability of a company in the entire Nordic- Baltic region. This presumably decreases potential Russian willingness to politically interfere in its energy companies' electricity supplies.

During the debates over the future of the Estonian electricity sector, its biggest energy company, Eesti Energia has diversified its corporate portfolio. Having the most extensive know- how in oil shale utilization, Eesti Energia has expanded its operations in recent years. Although the company has produced oil from oils shale since 1980, mainly to substitute expensive masut in district heating, but due to rising oil prices at the global market and to evolution of technologies, an option has emerged to use oil shale oil in producing high- value fuel oil and chemicals. ${ }^{227}$ In June 2009, Eesti Energia announced that it had developed a new oil shale oil production technology in collaboration with a Finnish technology company Outotec. ${ }^{228}$ The collaboration will also result in building a thermal unit to Estonia, over the years 2010- 2012, significantly increasing its oil shale oil production capacity. The long term plan is to build three Enefit280 oil shale oil production units in Auvere, Estonia. ${ }^{229}$ In addition, Eesti Energia has invested in renewable energy sources, such as the 39MW Aulepa wind farm. ${ }^{230}$ In absolute numbers, however, it is still merely a fraction of Estonian energy production as it constitutes less that $2 \%$ of total installed capacities. Growth of electricity production from renewable sources has

\footnotetext{
${ }^{227}$ Majandus.Delfi.ee, „Eesti ehitab veel ühe põlevkivi tehase (Estonia will build another oil shale oil factory),“ 23 November 2005, (URL: http://uudised.err.ee/index.php?0533972\&print=1) and Eesti Energia home page, Põlevkiviõli tootmine (Production of oil shale oil), URL: https://www.energia.ee/et/power/oilshale/oil

${ }^{228}$ Ott Heinapuu, ,Eesti Energia sõlmis 1,7- miljardilise lepingu põlevkiviõli tehase ehitamiseks (Eesti Energia strikes deal to to build a 1,7 billion (110 million euros) oil shale oil factory)," Eesti Päevaleht, 10 July 2009.

${ }^{229}$ Harri Mikk, "Koduse vedelkütuste tootmise arendamine on kõige alus (Domestic liquid fuels production development is the basis to everything)," Eesti Energia Blog, 15 April 2011, URL:

https://www.energia.ee/en/about/presscentre/blog/-/asset_publisher/1mS7/content/blog_20110415_oil

${ }^{230}$ Eesti Energia, 2009- 2010 Annual Report, p 42, URL:

https://www.energia.ee/c/document_library/get_file?uuid=e3c0a636-963c-466e-b017-

7e2bde5ed4c7\&groupId=10187
} 
nevertheless been significant. With the completion of the Aulepa wind farm, the total electricity produced from wind had risen to $157 \mathrm{MW}$ and total electricity production from renewable energy sources had risen by $70 \%$ compared to a year earlier. ${ }^{231}$ The total capacity of projected wind farms is currently $844.2 \mathrm{MW}$, which is a rather large number that potentially could cover the total Estonian electricity demand during the summer and half of it during winter time. ${ }^{232}$ But due to randomness of wind farms' electricity production, the capacity cannot be taken into account when calculating security of supply during peak consumption. ${ }^{233}$

Eesti Energia has also expanded its activity beyond Estonian borders. In 2006, the company announced it had agreed to a MoU with the Jordanian government to explore the Jordanian oil shale deposits. ${ }^{234}$ It has become the company's largest development project outside of Estonia. Eesti Energia, boasting the best oil shale technology in the world, is currently undertaking preparations to build an energy complex that will provide both electricity (900MW) and oil shale oil (38000 barrels per day) from the Attarat Um Ghudran deposit. ${ }^{235}$ More recently, the company announced that the US government had approved a deal signed between Oil Shale Exploration Company and Eesti Energia that allows the Estonian energy company to start to prepare to build an oil shale oil production facility, with the capacity of 57000 barrels per day, in Utah. ${ }^{236}$ The company has also announced a deal giving it rights to explore oil shale deposits in Morocco. ${ }^{237}$

This recent and rapid expansion has generated some resonance in the Estonian media. A former electricity and heat producer is growing into a big energy company with a global reach. Andres Reimer of the Estonian daily Eesti Päevaleht argues that the state is no longer able to control the energy sector. ${ }^{238}$ On the contrary, due to significantly abundant resources, Eesti Energia is the only entity wealthy enough to order relevant research in the field, and thus able to direct policy in

\footnotetext{
${ }^{231}$ Maris Meiessaar, "Eesti taastuvenergia toodang on aastaga tõusnud 50\% võrra,” Eesti Päevaleht, 27 April 2011.

232 Ibid.

${ }^{233}$ Elering 2010, p 12.

${ }^{234}$ Eesti Päevaleht, „Eesti Energia asub uurima Jordaania põlevkivivarusid (Eesti Energia starts to explore Jordanian oil shale deposits), “ 6 November 2006.

${ }^{235}$ Eesti Energia, „Eesti Energia allkirjastas Jordaania valitsusega põlevkivivarude kasutamise lepingu (Eesti Energia signed a oil shale deposit use deal with the Jordanian government), " press release, 12 May 2010, URL: https://www.energia.ee/et/about/presscentre/start/-/asset_publisher/OM2b/content/modalwindow/130578

${ }^{236}$ Eesti Energia, „USA andis heakskiidu Eesti Energia plaanidele (USA approved Eesti Energia’s plans),“ press release, 16 March 2011 , URL: https://www.energia.ee/et/oil/start/americanoil\#planFourHidden

${ }^{237}$ Postimees, "Eesti Energia saab õiguse Marokos põlevkivivarusid uurida (Eesti Energia receives right to explore Moroccan oil shale deposits)," 26 March 2010.

${ }^{238}$ Andres Reimer, „Firma, mis paisus üle serva (The company that swoll over the edge),“Eesti Päevaleht, 9 June 2010 .
} 
Estonia. The state's know- how is limited to one "star-bureaucrat," Einari Kisel, the Deputy Secretary General of Energy in the Ministry of Economic Affairs and Communications (and a former employee of Eesti Energia), who is dependent on the energy company for information. According to another daily, Postimees, Eesti Energia is "not excited" to invest in oils shalefuelled electricity production capacities as the profitability of producing electricity from one ton of oil shale is five euros whereas it makes thirty euros from producing oil from the same amount of oil shale (granted that the global oil price is at 100 dollars per barrel). ${ }^{239}$ Hence, there is a discrepancy between state and corporate interests: profitability does not translate into energy security. Because Eesti Energia is owned by the state, it will have to follow the government's policies but due to an increasing information and resource asymmetry, the company is able, to some extent, to direct government energy policy.

The data shows that Estonian resistance to EU policies, and thus to Europeanization, seems to come from security concerns. In Estonia, the trinity of policy goals- creation of an internal market, security of supply and environmental sustainability- are contradictory. Security of supply is being undermined by higher environmental standards and by opening of the market. The situation is likely to lead to the demise of oil shale- fuelled electricity production, but because of continuous demand of oil shale as a fuel in the chemical industry and in producing liquid fuels, the oil shale sector is likely survive and is even to grow. In 2010, the Ministry of Economic Affairs and Communications projected a small but gradual decrease in employment in Estonia's mining industry. ${ }^{240}$ In the electricity industry, a $10 \%$ decrease in employment is projected, due to opening of the electricity market and decrease in its competitiveness. ${ }^{241}$

At the same time, Annex 5 to the State Oil Shale Usage Development Plan reveals a significant impact from the mining industry to the living conditions and life quality of the people in the mining region. Interviews with the local population show that the people in the region see nothing positive about the existence of oil shale mines and the general attitude towards mining is

\footnotetext{
${ }^{239}$ Postimees, „Andrus Ansip: Eesti Energia pääses Tallinna Vee saatusest (Prime Minister Andrus Ansip: Eesti Energia avoids the fate of Tallinna Vesi),“31 March 2011.

${ }^{240}$ Ministry of Economic Affairs and Communications, "Employment projections until 2016," $2009: 14$.

${ }^{241}$ Ibid., p 46- 47.
} 
rather negative as the fact that "there is valuable oil shale under the Ida- Viru County's landowner's land has brought them nothing but concern and misery."242

Interestingly, it was also opined that because the Estonian Russian- speaking population is mainly employed in Ida- Viru County, its employment rates are "artificially" sustained as miners are working part- time. ${ }^{243}$ The county that is mainly populated by a Russian- speaking minority (71,4\% of the county's population and $35,7 \%$ of the Estonian Russian- speaking minority $)^{244}$, and its industries that are the largest employers of the minority, are of vital interest from the perspective of the government because a social crisis in the region can have a destabilizing effect on the entire country. Integration of the Russian- speaking minority $(25.5 \%$ of Estonian population) has not been as successful as expected and a significant decrease of employment in Ida- Viru County could further worsen to the situation. Moreover, Russia is notorious for being concerned with how its nationals are being treated in its 'near- abroad'. But, as employment projections and the developments in oil shale technology show, it is unlikely that the opening of the electricity market will result in a social crisis that would have some more serious consequences.

Hence, the most probable explanation for the government's resistance to EU energy policy is concerns over energy security. However, dependence on Russian electricity supply may only be considered as a long- term threat and only in a situation where Estonian electricity generation capacities have been shut down or conserved, and when Russian electricity is imported to an extent that interconnection capacity cannot compensate for a supply failure.

The EU's energy internal market and climate policy appears to also backfire against its objective of improving the energy- related investment environment in the Baltic States. Due to EU climate policy and the small size of the Baltic electricity markets, it is difficult to find foreign investments to support building new electricity generation capacities. Eesti Energia is planning on building two new energy blocs to the Narva Power Plants with collaboration with a French technology company Alstom. The deal reportedly enjoys a 90 million Euro subsidy from the

\footnotetext{
${ }^{242}$ Annex 5 to the State Oil Shale Usage Development Plan, Ministry of Economic Affairs and Communications, 2008.

${ }^{243}$ Ibid., p 3.

${ }^{244}$ Statistics Estonia, www.stat.ee
} 
Estonian government, which is seen as unfair under the rules of open and fair competition. ${ }^{245}$ However, there is a possibility that this aid will be prohibited by the Commission. If so, the project would have to be financed by a loan, thus substantially raising the cost of the project to Eesti Energia that will result in higher electricity prices and an even greater competitive advantage to Russian producers. The other example comes from Lithuania, where, similar to Estonia, it was agreed during its accession negotiations with the EU that the Chernobyl- type Ingalina Nuclear Power Plant, that accounted for $70 \%$ of Lithuanian electricity supply, would have to be closed before 2010 (the first reactor was closed in 2004). The Lithuanian government had looked for an investor that would help finance the construction of a new nuclear power plant within a decade, and it was reported in November 2010 that it had finally found one in a Korean energy company KEPCO. ${ }^{246}$ The company, however, unexpectedly withdrew from the deal. The exact reasons are unknown, but Lithuanian experts tend to think that the main reasons were the small size of the electricity market and its inability to compete with other producers in the region. ${ }^{247}$ At the same time, the Baltiiski Nuclear Power Plant is being built in Kaliningrad, the Russian enclave between Lithuania and Poland, at the Baltic Sea, just 15 kilometers from the Lithuanian border. ${ }^{248}$ The capacity of the plant will consist of two $1190 \mathrm{MW}$ reactors, with the total capacity of $2400 \mathrm{MW}$. It is clear that the reactors are built with export in mind as the total electricity demand of Kaliningrad is $1000 \mathrm{MW} .{ }^{249}$ Four new reactors are also being built in Sosnovõi Bor, near St. Petersburg, but they are meant to gradually replace the old Chernobyltype ones. Recently, Russia and Belarus signed a $\$ 9.4$ billion loan agreement, according to which a nuclear plant will be built by the Russians to Belarus, near to the Lithuanian border. ${ }^{250}$ It will be operational in 2018. All of these examples lead one to think that the opening of the Baltic electricity markets, closure of installed generation capacities and higher environmental standards create opportunities for third countries to take advantage of the emerging situation, especially because electricity prices in the EU are significantly higher.

\footnotetext{
${ }^{245}$ Mirko Ojakivi, „Eesti Energia võib rivaalide kiusu tõttu rahata jääda (Eesti Energia might end up without the money due to rivals’ obstinacy)," Eesti Päevaleht, 3 December 2010.

${ }^{246}$ Andres Mäe, ,Leedu tuumajaam: nurjumise õppetunnid (The Lithuanian Nuclear Power Plant: lessons of failure),“Eesti Päevaleht, 7 December 2010.

247 Ibid.

${ }^{248}$ Jaanus Piirsalu, „Venemaa surub Baltimaadele jõuliselt peale oma elektrit, aga Leedus ei jõuta kokkuleppele (Russia vigorously imposes its electricity to the Baltic states while there is no agreement in Lithuania)," Eesti Päevaleht, 7 July 2010.

${ }^{249}$ Ibid.

${ }^{250}$ Radio Free Liberty, „Russia, Belarus Ink \$9 Billion Nuclear Deal Despite Activists’ Efforts,“ 15 March 2011.
} 
As we can see, Europeanization of the Estonian electricity sector has not yet been successful because of the Estonian government's resistance to change and because of the politician's inability to make decisions over how to secure electricity supply in the future. More fundamental reasons lie in the historical legacy of the electricity sector, the small size of the Estonian market, the relative poverty of the country and the Estonian decision- makers' inability to decide for the future development of the sector. Complying with the different EU energy policy directions means a fundamental change in the electricity industry. It is difficult to make such changes in a relatively short time and it is politically unpopular as it results in higher electricity prices, significantly increasing both production costs for Estonian companies and living costs for the population. A rise in electricity prices is however inevitable as they have been held at one of the lowest levels in the EU because the environmental cost of electricity production has not been included in the prices. The evidence appears to indicate, mainly due to the examples of Estonian lobby against market opening for third party states and contesting emission allowances, that the Estonian main argument against change has been energy security. Thus, hypothesis 6 (Estonia's resistance to Europeanization of the electricity sector is due to energy security concerns) appears to be correct. The situation, however, is more complex. As I have shown, concerns over becoming dependent from Russian electricity imports can threaten Estonian energy security only in the long run and under specific condition. Hence, the argument over energy security is perhaps more of a pretext to protect its oil shale industry from unfair competition rather than a real security concern. The evidence also indicates that Estonian opposition to Europeanization of the electricity sector is not due to concerns over a possible social crisis in Ida- Viru County either. Hence, hypothesis 7 (Estonia's opposition to Europeanization of the electricity sector is due to concerns over a possible social crisis in Ida- Viru County) is also incorrect. 


\section{Conclusions}

Research indicates that Europeanization of the Estonian electricity sector has been, to an extent, successful. The required changes in Estonian legislation have been introduced, but the relevant government policies and the reality of the sector do not fully coincide with the principles of EU energy- and climate policies. Thus, evidence from the process of Europeanization in the Estonian electricity sector allows us to conclude that there are limits to Europeanization.

The literature suggests that a precondition to Europeanization is a "misfit" between EU and Member State policies that leads to adaptational pressures for the various facilitating actors. In the case of the Estonian electricity sector the facilitating actors are the Government of the Republic of Estonia, which interferes in the sector through different ministries and their subordinate agencies, and the country's largest energy company- Eesti Energia.

The most significant misfit between the EU and domestic level policies is the historical legacy of the Estonian electricity sector. Namely, it is the large oil shale industrial complex that was built during the Soviet period. It produces over $90 \%$ of Estonian electricity at one of the lowest prices in Europe. Oil shale is sometimes considered to be a national wealth as it provides cheap electricity and heating, jobs, revenues for the state budget and energy self- sufficiency. But because it is powered by fossil fuels, it also generates most of Estonian air, water and land pollution. During Soviet rule, no attention was paid to environmental protection. For this reason, electricity production and the oil shale mines in the northeastern part of Estonia have a great impact on the environment and living conditions of the local population. It can thus be also seen as a national encumbrance.

The aim of the EU energy and climate policy is to incorporate the real external costs (i.e. environmental and social costs) to the electricity price. Because of the benefits and national importance of the oil shale complex, Estonia is opposing change despite the apparent costs of the "national wealth." Research shows that the continuing influence of the historical legacies on Estonian politics is reinforced by additional conditions. The small size of the Estonian electricity market that does not allow proper market functioning as it does not provide sufficient incentives for large long- term investments to electricity production that would help to restructure the Estonian electricity market while providing security of supply. The relative poverty of Estonia has led to prioritizing high rates of economic growth that, among other things, require cheap 
production costs such as low electricity prices. To achieve this, environmental costs of electricity production had to be ignored. Another factor is the politicians' inability to decide over the future of the Estonian electricity sector. Currently, it has not been decided what will happen to the Estonian electricity sector after the Estonian electricity market completely opens in 2013 . There is a great deal of uncertainty about the future but any decision would be unpopular as it would inevitably lead to substantially higher electricity prices.

In order to find the abovementioned factors and to evaluate their impact on Europeanization of the electricity market, the empirical part of the thesis was divided into three parts. This is due to the different mechanisms of Europeanization, depending on the relationship between the EU and the state. In the first period, when Estonia was a newly independent and in a transitional state (1991-1995), it showed signs of valuing the principles of a market economy with free and fair competition in the electricity market. But because of economic constraints, the desired changes could not have been implemented. A greater degree of economic, financial and political stability had to be achieved first. The evidence thus shows that Estonia generally shared similar values, beliefs and norms with the EU, but their implementation was greatly limited by the realities of the economy and the electricity sector.

In the second period, when Estonia was an EU candidate state, the transition and restructuring of the economy continued. Due to a greater deal of EU influence, the change was both facilitated and accelerated by the EU. In order to meet EU requirements, Estonia quickly adopted new legislation and implemented structural changes in the electricity sector to prepare it for privatization. The latter process was, however, halted by Estonia's quick economic growth and political struggles. Even though the process of privatization did not succeed, Europeanization of the electricity sector continued under state ownership. To meet EU environmental and safety standards, renovation of the oil shale power plants had begun. The EU's use of conditionality was relatively weak. Estonia had to adopt relevant legislation, but it was also allowed two long transitional periods: for market opening and renovating its old power plants. Hence, the process of Europeanization is best described by shared values, beliefs and norms. The importance and the unique characteristics of the Estonian electricity sector were recognized by the EU which possibly explains the absence of extensive use of conditionality through external incentives. 
In the third period, after Estonia had become an EU Member State (2004- 2011), its economy had substantially changed, but the limits caused by the smallness of the market, the historical legacies and relative poverty remained. An important factor is also the fact that no further substantial reforms were implemented or even planned during the first four years of Estonia's status as an EU Member State. The most important policy documents related to the electricity sector weren't signed until 2007 and 2008. Analysis shows that the political decisions to develop the electricity sector were not far- sighted, to an extent contradicted with the principles of EU energy- and climate policy and did not properly take into account the emerging situation in the electricity market. Instead, the government lobbied against implementing changes that were required by the EU. The main arguments were the substantial decrease in competitiveness of the Estonian electricity producers and an emerging threat to Estonian energy security. Research shows that neither of the two positions is completely adequate. The government has aimed to protect the oil shale complex from foreign competition, but has failed to create an enabling domestic investment environment. It appears that Eesti Energia can survive as a company by diversifying its production portfolio. But it cannot continue to hold over $90 \%$ of the Estonian electricity market.

Thus, it is evident that the EU energy- and climate policies are at odds with reality in the case of Estonia. For Estonia, it is not possible, at least in the short- run, to maintain domestic security of electricity supply while meeting the EU's requirements of environmental sustainability and opening its electricity market. The main drivers of developing the policy are the large Member States such as Germany, France and the United Kingdom. Their legacies, markets and general economic environments are, however, substantially different than that of Estonia. Thus, a 'misfit' between EU and Estonian policies is understandable. But because the electricity sector is of vital importance from the perspective of the state and its economy, Estonia has opposed change in its electricity sector.

At the same time, Estonia has been able to find solutions to the challenges. It has built (or is currently building) connections with Finland and has joined the Nord Pool electricity exchange to provide relief for security concerns. Eesti Energia, on the other hand, has developed new technologies that will help it to survive by shifting focus from electricity production to producing liquid fuels that creates more revenue and enables it to maintain jobs. 


\begin{abstract}
Although the Estonian electricity market is quite unique, the case study provides us with useful insights about the process of Europeanization and about power relations in the EU. EU- wide policies that are driven by large Member States, such as Germany, France and United Kingdom, may not take into account peculiar conditions in the EU's borderlands. The Estonian case shows that this may lead a vulnerable Member State to use arguments such as national security to gain support to its position and to defend its interests. These conclusions may be useful for future EU policy- making, especially when dealing with potential new candidate states such as Ukraine or the South Eastern European States.
\end{abstract}




\section{Bibliography \\ Primary sources}

EEA Report: Energy and Environment in the European Union. No 8/2006.

Eesti Energia official website. Põlevkiviõli tootmine (Production of oil shale oil). URL: https://www.energia.ee/et/power/oilshale/oil (Accessed 13 May 2011).

Eesti Energia. 2009- 2010 Annual Report. URL:

https://www.energia.ee/c/document_library/get_file?uuid=e3c0a636-963c-466e-b0177e2bde5ed4c7\&groupId=10187 (Accessed 13 May 2011).

Eesti Energia. Energeetika ajalugu. URL:

https://www.energia.ee/c/document_library/get_file?uuid=3cbe8bd1-611e-45a5-b6ed4f69f69cbee1\&groupId=10187 (Accessed 13 May 2011).

Einari Kisel. "Arengud Euroopa Liidu energeetikaalases seadusandluses (Developments in the European Union energy- related legislature).” presentation at the Alternatiivid ja valikud energeetikas (Alternatives and choices in energy policy)- conference, hosted by the Eesti Jõujaamade ja Kaugkütte Ühing (The Estonian Power Plants and District Heating Association, 23-24 April 2009.

Estonian Energy Market Inspectorate, Report on the Estonian Electricity and Gas Markets (for the European Commission), Tallinn, 2006.

Estonian Energy Market Inspectorate. Report on the Estonian Electricity and Gas Markets (for the European Commission). Tallinn, 2009.

Estonian Ministry of Economic Affairs and Communications. Estonian Energy in Figures. Tallinn, 2007.

Estonian Ministry of the Environment. Estonian National Oil Shale Usage Development Plan 2008- 2015. Tallinn, 2008.

EurActiv.com. "EU industry and the 'carbon leakage' threat." URL:

http://www.euractiv.com/en/climate-environment/eu-industry-and-carbon-leakage-threatlinksdossier-188482 (Accessed 13 May 2011). 
Europa.eu. "Emissions trading: EU- wide cap for 2008- 2012 set at 2.08 billion allowances after assessment of national plans for Bulgaria." press release. URL:

http://europa.eu/rapid/pressReleasesAction.do?reference=IP/07/1614\&format=HTML\&language =EN (Accessed 13 May 2011).

European Commission. Estonian Progress Report for the Commission Review. 2002.

European Commission. Estonian Progress Report for the Commission Review 2001. URL: http://www.envir.ee/52169 (Accessed 13 May 2011).

European Commission. Estonian Progress Report for the Commission Review 2001. URL: http://www.envir.ee/52174 (Accessed 13 May 2011).

European Commission. Green Paper: A European Strategy for Sustainable, Competitive and Secure Energy. 2006.

European Commission. Summary of Estonia's adoption of the energy related community acquis. URL:

http://europa.eu/legislation_summaries/enlargement/2004_and_2007_enlargement/estonia/e1410 2_en.htm (Accessed 13 May 2011).

European Council conclusions of 16- 17 June 1998. Council Document 9702/98.

European Council document C(2009) 10251.

European Council document C(2009) 10251, URL: http://eurlex.europa.eu/LexUriServ/LexUriServ.do?uri=OJ:L:2010:001:0010:0018:EN:PDF (Accessed 13 May 2011).

European Environmental Agency, Indicator EN31: http://www.eea.europa.eu/data-andmaps/indicators/en31-energy-prices (Accessed 13 May 2011).

Government of Estonia. Estonian European Union Policy 2007- 2011. Tallinn, 2007.

Government of Estonia. Principles of Estonian Security Policy. Tallinn, 2007.

IEA. World Energy Outlook. 2010. 
Judgments of the Court of First Instance in the Case T- 183/07 and in Case T- 263/07. URL: http://curia.europa.eu/jcms/upload/docs/application/pdf/2009-09/cp090076en.pdf (Accessed 13 May 2011).

Ministry of Economic Affairs and Communications. Estonian Electricity Economy Development Plan. Tallinn, 2008 .

Ministry of Economic Affairs and Communications. Estonian Electricity Economy Development Plan until 2018. Tallinn, 2008.

Ministry of Economic Affairs and Communications. Estonian Energy 1997. URL: http://www.mkm.ee/doc.php?1790 (Accessed 13 May 2011).

Ministry of Economic Affairs and Communications. Estonian Energy 1994- 1996. URL: http://www.mkm.ee/public/Eesti_Energeetika_1994-1996.pdf (Accessed 13 May 2011).

Ministry of Economic Affairs and Communications. Estonian Energy 1991- 2000. URL: http://www.mkm.ee/public/E_Energeetika_1991-2000.pdf (Accessed 13 May 2011).

Ministry of Economic Affairs and Communications. Estonian National Energy Economy Development Plan until 2020. Tallinn, 2008.

Ministry of Economic Affairs and Communications. Fuel- and energy economy long- term development plan. Tallinn 1997.

Ministry of Economic Affairs and Communications. Fuel- and energy economy long- term development plan. 1997. (Accessed 13 May 2011).

Ministry of the Environment. Estonian Environmental Action Plan 2007- 2013. Tallinn, 2007.

Ministry of the Environment. Estonian Environmental Strategy until 2030. Tallinn, 2007.

National Audit Office of Estonia, press release, 12.04.2000, URL: http://www.riigikontroll.ee/Suhtedavalikkusega/Pressiteated/tabid/168/dnn_ctr557_Article_List_ paginationDBControlGetPage/2/dnn_ctr557_Article_List_yearSelectControlYear/2000/ItemId/35 4/amid/557/language/et-EE/Default.aspx (Accessed 13 May 2011). 
Riigi Teataja Võrguväljaanne (Online version of Official Journal of Estonia). URL: Www.riigiteataja.ee (Accessed 13 May 2011). RT 1991, 14, 204.

Riigi Teataja Võrguväljaanne (Online version of Official Journal of Estonia). URL: www.riigiteataja.ee (Accessed 13 May 2011). RT 1991, 2, 21.

Riigi Teataja Võrguväljaanne (Online version of Official Journal of Estonia). URL: www.riigiteataja.ee (Accessed 13 May 2011). RT 1991, 22, 259.

Riigi Teataja Võrguväljaanne (Online version of Official Journal of Estonia). URL: www.riigiteataja.ee (Accessed 13 May 2011). RT 1991, 32, 406.

Riigi Teataja Võrguväljaanne (Online version of Official Journal of Estonia). URL: www.riigiteataja.ee (Accessed 13 May 2011). RT 1991, 4, 69.

Riigi Teataja Võrguväljaanne (Online version of Official Journal of Estonia). URL: www.riigiteataja.ee (Accessed 13 May 2011). RT 1992, 28, 390.

Riigi Teataja Võrguväljaanne (Online version of Official Journal of Estonia). URL: Www.riigiteataja.ee (Accessed 13 May 2011). RT 1992, 41, 544.

Riigi Teataja Võrguväljaanne (Online version of Official Journal of Estonia). URL: Www.riigiteataja.ee (Accessed 13 May 2011). RT 1992, 6, 98.

Riigi Teataja Võrguväljaanne (Online version of Official Journal of Estonia). URL: Www.riigiteataja.ee (Accessed 13 May 2011). RT 1994, 40, 1366.

Riigi Teataja Võrguväljaanne (Online version of Official Journal of Estonia). URL: www.riigiteataja.ee (Accessed 13 May 2011). RT I 1998, 5, 74.

Riigi Teataja Võrguväljaanne (Online version of Official Journal of Estonia). URL: www.riigiteataja.ee (Accessed 13 May 2011). RT I 2005, 58, 462.

Riigi Teataja Võrguväljaanne (Online version of Official Journal of Estonia). URL: www.riigiteataja.ee (Accessed 13 May 2011). RTL 1997, 99, 589. 
Riigi Teataja Võrguväljaanne (Online version of Official Journal of Estonia). URL: www.riigiteataja.ee (Accessed 13 May 2011). RTL 1998, 34, 181.

Riigi Teataja Võrguväljaanne (Online version of Official Journal of Estonia). URL: www.riigiteataja.ee (Accessed 13 May 2011). RTL 2002, 23, 326.

Riigi Teataja Võrguväljaanne (Online version of Official Journal of Estonia). URL: Www.riigiteataja.ee (Accessed 13 May 2011). RTL 2003, 24, 352.

\section{Online resources}

Riigikogu. official website of the Parliament of Estonia. URL: www.riigikogu.ee (Accessed 13 May 2011).

Riigi Teataja Võrguväljaanne (Online version of Official Journal of Estonia). URL: www.riigiteataja.ee (Accessed 13 May 2011).

\section{Secondary sources}

\section{Books and journal articles}

Abbott, Malcolm. "Is The Security of Electricity Supply a Public Good?" Electricity Journal $8(2001)$.

Auer, Matthew R. Restoring Cursed Earth: Appraising Environmental Policy Reforms in Eastern Europe and Russia. Rowman \& Littlefield, 2005.

Bache, Ian. Europeanization and multilevel governance: cohesion policy in the European Union and Britain. Rowman and Littlefield, 2008.

Bauby, Pierre and Frédéric Varone. "Europeanization of the French electricity policy: four paradoxes.” Journal of European Public Policy 14(2007).

Bielecki, Janusz. "Energy security: is the wolf at the door?" The Quarterly Review of Economics and Finance 42(2002).

Bohi, Douglar R. and Michael A. Toman. The Economics of Energy Security. Norwell: Kluwer, 1996. 
Burinskiene, Marija and Paulius Rudzkis. "Feasibility of the liberal electricity market under conditions of a small and imperfect market. The case of Lithuania." Technological and Economic Development of the Economy Report, (2010). URL:

http://www.thefreelibrary.com/Feasibility+of+the+liberal+electricity+market+under+conditions+ of+a...-a0241861721 (Accessed 13 May 2011).

Buzan, Barry, Ole Wæver and Jaap de Wilde. Security: a new framework for analysis. Lynne Rienner Publishers, 1998.

Börzel, Tanja A. and Thomas Risse. "Conceptualizing the Domestic Impact of Europe." In The Politics of Europeanization, ed. Keith Featherstone and Claudio Radaelli. Oxford Universtiy Press, 2003.

Chubais, Anatoly. "Final Stages in the Reform of RAO UES of Russia- Future Developments in the Russian Energy Market.” In Handbook of Utility Management, ed. A. Bausch and B. Schwenker. Berlin: Springer, 2009.

Cirtautas, Arista Maria and Frank Schimmelfennig. "Europeanization Before and After Accession: Conditionality, legacies and Compliance.“ European-Asia Studies 62(2010).

Convery, Frank J. "Origins and the development of EU ETS.“ Environmental and Resource Economics 43(2009).

Deitz, Laura, Lindsay Stirton and Kathryn Wright. “South East Europe’s electriicty sector: Attractions, obstacles and challenges of Europeanization.“ Utilities Policy 17(2009).

Eberlein, Burkard. “The Making of The European Energy Market: The Interplay of Governance and Government.“ Journal of Public Policy 28(2007).

Eising, Rainer. "Policy Learning in Embedded Negotiations: Expalining EU Electricity Liberalization." International Organization 56(2002).

Featherstone, Kevin and Claudia Maria Radaelli. The politics of Europeanization. Oxford University Press, 2003. 
Hadfield, Amelia. “EU- Russia Energy Relations: Aggregation and Aggravation.” Journal of Contemporary European Studies 16(2008).

Haghighi, Sanam S. "Energy Security and the Division of Competences between the European Community and its Member States.” European Law Journal 14 (2008): 461- 482.

Haughton, Tim. "When Does the EU Make a Difference? Conditionality and the Accession Process in Central and Eastern Europe.” Political Studies Review 5(2007).

Hysmans, Jef. "Security! What Do You Mean? From Concept to Thick Signifier," European Journal of International Relations 4(1998).

Knill, Cristoph and Dirk Lehmkull. "The national impact on European Union regulatory policy: Three Europeanization mechanisms.“ European Journal of Political Research 41(2002).

Laur, Anton, Koidu Tenno and Sulev Soosaar. "Development of Electricity Markets- Options for Estonia." In Essays in Estonian Transformation Economics, ed. Ü. Ennuste and L. Wilder, 211244, (Tallinn: Estonian Institute of Economics at TTÜ, 2005).

Levi- Faur, David. 'On the 'Net Impact' of Europeanization: The EU's telecoms and electricity regimes between the global and the national.” European Integration online Papers 6(2002).

Meidan, Mihal. "Perceptions and Misperceptions of Energy Supply Security in Europe and the 'China Factor.“ In Energy Security: Visions from Asia and Europe, ed. Antonio Marquina. New York:Palgrave Macmillan, 2008.

Mäe, Andres. "Estonia's energy security and the European Union.” Estonian Foreign Policy Yearbook. Ed. Andres Kasekamp. Tallinn: Estonian Foreign Policy Institute, 2007.

Olcott, Martha Brill. "The Great Powers in Central Asia.” Current History October (2005). Olsen, Johan P. “The Many Faces of Europeanization.“ Journal of Common Market Studies 40(2002).

Pointvogl, Andreas. "Perceptions, realities, concession- what is driving the integration of European Energy Policies.” Energy Policy 37(2009). 
Ramus, Catherine A. "The Large Combustion Plant Directive: An Analysis of European Environmental Policy." Oxford Institute of Energy Studies paper EV7 (1991).

Raun, Toivo U. Estonia and the Estonians. Stanford: Hoover Institution Press, 2001.

Schimmelfenning, Frank and Ulrich Sedelmeier. The Europeanization of Central and Eastern Europe. Cornell University Press, 2005.

Sedelmeier, Ulrich. "Europeanization in new member states and candidate states." Living Reviews in European Governance 6(2011).

Sepos, Angelos. The Europeanization of Cyprus: Polity, Policies and Politics. New York: Palgrave, 2008.

Serrallés, Roberto J. "Electric energy restructuring in the European Union: Integration, subsidiarity and the challenge of harmonization.” Energy Policy 34(2006).

Streimikeine, Dalia, Inge Roos and Janis Rekis, "External cost of electricity generation in Baltic States," Renewable and Sustainable Energy Reviews, (2008).

Tsahkna, Anna- Greta. "Euroopa Liidu liberaliseerimispoliitika mõju Eesti elektriturule (Impact of the European Union's liberalization policy to the Estonian electricity market).“ Master’s thesis, University of Tartu, Department of Economics, 2010.

Veiderma, Mihkel. "Estonian Oil Shale- Resources and Usage." Oil Shale 20(2003).

Verheijen, Susan. “The Baltic States' Electricity Policies. A Case Study of How the EU Influences the Baltic State Electricity Policies.“ Master's thesis, University of Tartu, 2009.

\section{Unpublished articles}

Domanico, Fabio. "Liberalization of the European Electricty Industry: Internal Market or National Champions.“ Worldenergy.org. URL: http://89.206.150.89/documents/p001227.pdf (Accessed 13 May 2011).

Ertuna, Tahsin Hakan. "Competition Law in the Electricity Market: Liberalization and its Consequences.“ Ankara Bar Review 2(2010). 
Keppler, Jan Horst, "International Relations and Security of Energy: Risks to Continuity and Geopolitical Risks." An external study for Directorate- General for External Policies of the Union: Policy Department. Brussels: European Parliament, 2007. URL: http://www.europarl.europa.eu/studies/default.htm (Accessed 13 May 2011).

Raukas, Anto, "Energy Crisis and Oil Shale Industry,” Unpublished, 2010.

\section{Articles in newspapers and press releases}

Editorial. “Elektrijaamad konkursile.” Äripäev, 6 November 1997.

Eesti Energia. "Eesti Energia allkirjastas Jordaania valitsusega põlevkivivarude kasutamise lepingu (Eesti Energia signed a oil shale deposit use deal with the Jordanian government)." press release, 12 May 2010. URL: https://www.energia.ee/et/about/presscentre/start//asset_publisher/OM2b/content/modalwindow/130578 (Accessed 13 May 2011).

Eesti Energia. "USA andis heakskiidu Eesti Energia plaanidele (USA approved Eesti Energia's plans).“ press release, 16 March 2011. URL: https://www.energia.ee/et/oil/start/americanoil\#planFourHidden (Accessed 13 May 2011).

Eesti Päevaleht. "Eesti Energia asub uurima Jordaania põlevkivivarusid (Eesti Energia starts to explore Jordanian oil shale deposits).“ 6 November 2006.

ERR (Estonian National Broadcasting). "Euroopa Komisjon lükkas tagasi Eesti heitmekvoodikava (European Commission reject Estonian emissions quota plan).“ 29 April 2011. URL: http://uudised.err.ee/index.php?06228046 (Accessed 13 May 2011).

Heinapuu, Ott. "Eesti Energia sõlmis 1,7- miljardilise lepingu põlevkiviõli tehase ehitamiseks (Eesti Energia strikes deal to to build a 1,7 billion (110 million euros) oil shale oil factory)." Eesti Päevaleht, 10 July 2009.

Kurm, Kairi and Aleksei Gunter. "New power cable to unite Baltic and Scandinavian power supplies.” The Baltic Times, 11 October 2001.

Mäe, Andres. "Leedu tuumajaam: nurjumise õppetunnid (The Lithuanian Nuclear Power Plant: lessons of failure).“ Eesti Päevaleht, 7 December 2010. 
Majandus.Delfi.ee. "Eesti ehitab veel ühe põlevkivi tehase (Estonia will build another oil shale oil factory),“ 23 November 2005. URL: http://uudised.err.ee/index.php?0533972\&print=1 (Accessed 13 May 2011).

Meiessaar, Maris. "Eesti taastuvenergia toodang on aastaga tõusnud 50\% võrra." Eesti Päevaleht, 27 April 2011.

Mikk, Harri. "Koduse vedelkütuste tootmise arendamine on kõige alus (Domestic liquid fuels production development is the basis to everything)." Eesti Energia Blog, 15 April 2011. URL: https://www.energia.ee/en/about/presscentre/blog//asset_publisher/1mS7/content/blog_20110415_oil (Accessed 13 May 2011).

Niitra, Sirje. "Eesti Energia valmistub erastamiseks (Eesti Energia is preparing for privatization).“ Eesti Päevaleht, 28 November 1997.

Ojakivi, Mirko. "Eesti Energia võib rivaalide kiusu tõttu rahata jääda (Eesti Energia might end up without the money due to rivals' obstinacy)." Eesti Päevaleht, 3 December 2010.

Piirsalu, Jaanus. "Venemaa surub Baltimaadele jõuliselt peale oma elektrit, aga Leedus ei jõuta kokkuleppele (Russia vigorously imposes its electricity to the Baltic states while there is no agreement in Lithuania).“ Eesti Päevaleht, 7 July 2010.

Postimees. "Eesti Energia saab õiguse Marokos põlevkivivarusid uurida (Eesti Energia receives right to explore Moroccan oil shale deposits).” 26 March 2010.

Postimees. "NRG- tehing oli ennas ammendanud." 9 January 2002.

Postimees. “Andrus Ansip: Eesti Energia pääses Tallinna Vee saatusest (Prime Minister Andrus Ansip: Eesti Energia avoids the fate of Tallinna Vesi).“ 31 March 2011.

Radio Free Liberty. "Russia, Belarus Ink \$9 Billion Nuclear Deal Despite Activists’ Efforts." 15 March 2011.

Rafael Behr. Financial Times, 8 January 2002.

Reimer, Andres. "Firma, mis paisus üle serva (The company that swoll over the edge)." Eesti Päevaleht, 9 June 2010. 
Reuters. "Medvedev takes aim at Russia's state board members." 30 March 2011. URL:

http://www.reuters.com/article/2011/03/30/russia-medvedev-taxes-idUSLDE72T1HC20110330

(Accessed 13 May 2011).

Stephen Gardner. "Planning pollution in Estonia." The Digger blog, March 24 2011. URL:

http://blogs.euobserver.com/gardner/2011/03/24/planning-pollution-in-estonia/ (Accessed 13

May 2011).

John $\mathrm{H}$. Virginia University Libraries, ou=Acquisitions Department, 